\title{
Hogyan befolyásolták volna a Magyar Nemzeti Bank likviditási és finanszírozási előírásai a 2008-as válság hazai hatásait?*
}

\author{
Borkó Tamás - Herbert Evelyn - Székely Barnabás - Szomorjai Péter
}

A Magyar Nemzeti Bank (MNB) a pénzügyi válság tapasztalataira építve 2012-t követően több olyan, a bankrendszer egészét érintő likviditási és finanszírozási kockázatokat kezelö szabályozást vezetett be, amellyel ellenösztönözte a rövid és hosszabb távú fizetőképességet veszélyeztető üzleti gyakorlatok kialakulását. A devizális eltérést kezelö eszközök, mint a devizafinanszírozás megfelelési mutató, a devizaegyensúly mutató, a bankközi finanszírozási mutató, valamint az EU-szinten bevezetésre kerülő likviditásfedezeti ráta csökkentik a hazai, rendszerszintü likviditási és finanszírozási sokkok kialakulásának valószínüségét, illetve tartósan alacsonyan tarthatják a hazai bankrendszer rövid külső sérülékenységének mértékét. Elemzésünk az említett szabályozások hatásainak visszatesztelésével igazolja, hogy az eszköztár hatékony gátját képezhette volna a 2008-as válság előtt tapasztalható bankrendszeri sérülékenységek kialakulásának. Kijelenthető továbbá, hogy az eszköztár - a kockázatosabb finanszírozási gyakorlatok költségének bankrendszeri internalizálása révén - képes lehetett volna a később súlyos nemzetgazdasági és társadalmi hatásokkal járó devizahitel-állomány felépülési ütemének lassítására, valamint a túlzott hitelezéssel összefüggő kockázatok kialakulásának mérséklésére.

Journal of Economic Literature (JEL) kódok: E58, G01, G21

Kulcsszavak: pénzügyi stabilitás, likviditás, finanszírozás, makroprudenciális politika, rövid külső adósság, devizahitelezés

\section{Bevezetés}

A 2007-ben kezdődő válság a hitelpiacról rövid idő alatt tovább terjedt az USA egyéb pénzpiacaira ${ }^{1}$, illetve szétterjedt a globalizált pénzpiacon is. A válság rávilágított

\footnotetext{
* A jelen kiadványban megjelenő írások a szerzők nézeteit tartalmazzák, ami nem feltétlenül egyezik a Magyar Nemzeti Bank hivatalos álláspontjával.
}

Borkó Tamás a Magyar Nemzeti Bank vezetö közgazdasági elemzője. E-mail: borkot@mnb.hu Herbert Evelyn a Magyar Nemzeti Bank elemzője. E-mail: herberte@mnb.hu Székely Barnabás a Magyar Nemzeti Bank elemzője E-mail: szekelyb@mnb.hu Szomorjai Péter a Magyar Nemzeti Bank vezető felügyelője. E-mail: szomorjaip@mnb.hu

A szerzők köszönetet mondanak Grosz Gabriellának és Komlóssy Laurának a tanulmány elkészítésében való közreműködésükért, valamint Szakács Jánosnak az értékes észrevételekért. A fennmaradó hibák a szerzőket terhelik.

A magyar nyelvű kézirat első változata 2020. június 15-én érkezett szerkesztőségünkbe.

DOI: http://doi.org/10.25201/HSZ.19.4.2759

${ }^{1}$ Az amerikai jelzálogpiaci válság kitörésének okairól és következményeiről részletesen lásd: Dell'Ariccia et al. (2012) és Demyanyk - Hemert (2011). 
a likviditás jelentőségére a pénzügyi piacok és a bankszektor megfelelő múködésében. Korábban az élénk eszközpiacok mellett a finanszírozás alacsony költségekkel könnyen elérhető volt, a piaci viszonyok gyors átrendeződése azonban megmutatta, hogy a likviditás milyen gyorsan elpárologhat. A bankrendszer súlyos stresszhelyzetbe került, ami szükségessé tette a jegybankok fellépését a pénzpiacok, valamint némely esetekben az egyedi intézmények múködésének támogatására (BCBS 2013).

A pénzügyi válság gazdasági költségeinek mértéke megmutatta, hogy a pénzügyi rendszer stabilitása, a gazdaság alacsony sérülékenysége mennyire fontos egy ország megfelelő mértékű sokktűrő képességéhez. Rávilágított továbbá arra is, hogy a bankok egyedi stabilitását, prudens múködését biztosító, ún. mikroprudenciális beavatkozások önmagukban nem képesek megelőzni a jelentős reálgazdasági veszteségeket okozó pénzügyi zavarokat, és világossá vált, hogy makroprudenciális, a pénzügyi rendszer kockázatait rendszerszinten megközelítő beavatkozásokra is szükség van. A rendszerszintű pénzügyi kockázatok aktív visszaszorítása mellett a pénzügyi szereplők egyedi sokktűrő képességét is hathatós módon javítani kellett.

A likviditáskezelési hiányosságok kezelésére a válságot követően nemzetközi szintű válasz született: a Bázeli Bankfelügyeleti Bizottság két, egy-egy likviditási és finanszírozási ajánlást (BCBS 2013; BCBS 2014) dolgozott ki, amelyek alapján EU-szinten 2015-ben hatályba lépett a likviditásfedezeti ráta (Liquidity Coverage Ratio, LCR), illetve 2021-ben életbe lép a nettó stabil forrásellátottsági ráta (Net Stable Funding Ratio, NSFR). Ezek azonban nem minden esetben képesek kezelni a nemzeti szinten felmerülő kockázatok mindegyikét, így szükség lehet az EU-követelményeket kiegészítő nemzeti likviditási és finanszírozási szabályozásokra is.

A 2008-as válság közvetett módon a magyar bankrendszert is súlyosan érintette. Az ország akkori pénzügyi sérülékenysége elsősorban a lakossági devizahitelezéssel, valamint az ahhoz kapcsolódó devizafinanszírozási igényből eredő likviditási és szolvenciakockázatokkal hozható összefüggésbe. Az MNB a pénzügyi válság hazai tapasztalataira építve és a hazai pénzügyi rendszer sajátosságaira tekintettel a bázeli mutatók hatályba lépését megelőzően több olyan likviditási és finanszírozási kockázatokat kezelő szabályozást vezetett be, amellyel ellenösztönözte a rövid és hosszabb távú fizetőképességet veszélyeztető üzleti gyakorlatok kialakulását. A pénzügyi ciklus alján, lényegében minimális alkalmazkodási szükséglet mellett került bevezetésre a rövid lejáratú likviditási kockázatokat célzó, egyszerű LCR-mutatóként felfogható betétfedezeti mutató (BFM) és mérlegfedezeti mutató (MFM)², illetve a finanszírozási kockázatokat kezelő devizafinanszírozás megfelelési mutató (DMM), a devizaegyensúly mutató (DEM), a bankközi finanszírozási mutató (BFM), valamint a forint lejárati összhang biztosítását szolgáló jelzáloghitel-finanszírozás megfelelési mutató (JMM). Ezek a követelmények kiegészülve a már említett LCR-rel olyan preventív

\footnotetext{
${ }^{2}$ A két mutatót az LCR hatályba lépésekor az MNB kivezette az eszköztárból.
} 
eszköztárként müködnek, amelyek képesek csökkenteni a hazai rendszerszintű likviditási és finanszírozási sokkok kialakulásának valószínűségét, illetve emellett tartósan alacsonyan tarthatják a bankrendszer rövid külső sérülékenységének mértékét.

A válság óta felgyülemlett tapasztalatok alapján adódik a kérdés, és a koronavírus-világjárvány nyomán kibontakozó pénzügyi és gazdasági sokkhatásokra tekintettel pedig különösen fontos lehet, hogy milyen hozzávetőleges hatásokkal járhat egy ilyen szabályrendszer bevezetése. Ehhez egy gondolatkísérletben a pénzügyi világválság tapasztalatait használjuk fel: azt vizsgáljuk, hogy ha a válság előtt implementálták volna ezeket a szabályokat, akkor az mennyivel csökkentette volna a pénzügyi rendszer és ezáltal az egész gazdaság sérülékenységét. $A$ tanulmány célja tehát egyrészt annak a felmérése, hogy milyen hatással járt volna a szabályok 2007-2008-as válság előtti implementálása, másrészt annak a felmérése, hogy a jövőben miként akadályozhatja meg ez a keretrendszer a sérülékenységek felépülését és materializálódását - mivel ezek a tapasztalatok erről is nyújtanak információt.

Az így elvégzett visszatesztelési számítás arra enged következtetni, hogy a vizsgált szabályozói keret jelentősen csökkentette volna a bankközi rövid külső adósság szintjét. Eszközoldali alkalmazkodás esetén pedig a devizahitel-állománynak is érdemben csökkennie kellett volna, illetve eleve nem tudott volna felépülni a szabályozási korlátok miatt. Fontosnak tartjuk azonban megjegyezni, hogy az általunk végzett számítás elvégzéséhez több erős feltevéssel kellett élnünk, így - bár meggyőződésünk, hogy az eredmények rendszerszinten jó közelítést jelentenek - ez az elemzés csupán hozzávetőleges képet ad a szabályozói keretrendszer hatásairól.

A tanulmány első fejezete a likviditási és finanszírozási szabályozások fontosságáról ad elméleti és empirikus irodalmi áttekintést. A második fejezet bemutatja a hazai bankrendszer jellemzőit a 2007-2008-ban induló pénzügyi válságban, valamint a válságot követően alkalmazott likviditási és finanszírozási szabályozási eszközöket. A harmadik ismerteti az elvégzett kutatás részleteit, a negyedik pedig annak eredményeit. Végül a tanulmányt összegzéssel zárjuk.

\section{Likviditási és finanszírozási kockázatok}

\subsection{A likviditási és finanszírozási kockázatokról általánosan}

A hitelintézetek jellemzően lejárati transzformációt hajtanak végre a pénzközvetítés során, azaz a rövid lejáratú forrásaik terhére nyújtanak hosszabb lejáratú hiteleket. Ezáltal lehetővé teszik, hogy a hitelfelvevők simítsák a fogyasztási és beruházási ciklusukat, ami növeli a társadalom jóléti szintjét, de likviditási kockázatnak teszi ki a hitelintézeteket. 
A likviditás fogalmát hagyományosan úgy határozzák meg, hogy a hitelintézet képes finanszírozni az eszközök növekedését, és képes megfelelni a kötelezettségeinek azok esedékességekor (BCBS 2000). A szakirodalom szerint a bankok likviditási kockázatainak két különálló, de egymással összefüggő dimenziója létezik: a finanszírozási kockázat (hitelképesség a piacon), illetve a piaci likviditási kockázat (eszközpozíciók eladási vagy feloldási képessége) (ECB 2002). Előbbi annak a kockázata, hogy a hitelintézetek nem képesek, vagy csak a jövedelmezőség jelentős romlása árán tudják teljesíteni a fizetési kötelezettségeiket. Finanszírozási kockázatot többek között a bank által elérhető - egyedi problémák vagy a pénzpiaci likviditásszűke miatti - likviditás váratlan lecsökkenése, valamint nem várt forráskivonás vagy hitelkeret-lehívás nyomán hirtelen megugró likviditási igény eredményezhet. A finanszírozási kockázatot növeli, ha a bank forrásai között az ún. core-forrásnak minősülő ügyfélbetétek aránya alacsony, így a bank nagymértékben ráutalt az egyéb, kevésbé stabil forrásokra. A piaci likviditási kockázat annak a kockázata, hogy pénzpiaci zavarok nyomán a hitelintézet csak jelentős árveszteséggel tudja értékesíteni pénzügyi eszközeit, vagyis az egyébként likvid eszközök illikviddé válnak (Balás - Móré 2007; Sharma 2004). A finanszírozási és a piaci likviditási kockázatok szorosan kapcsolódnak egymáshoz, és visszahathatnak egymásra (Acharya - Schaefer 2005; Brunnermeier - Pedersen 2007). Ez a kölcsönös függőség kedvezőtlen körülmények között gyengítheti a pénzpiacokat, mivel az egy-egy részpiacot érintő zavarok könnyen átterjedhetnek egy másikra, ami az egész piac likviditását alááshatja.

A piaci és finanszírozási likviditási kockázatok közötti kölcsönhatást jól illusztrálta a 2007-ben kezdődött amerikai másodrendű jelzáloghitel-piaci válság. A befektetői bizalom megingásával a fedezett adósságkötelezvények (CDO-k) piaca egyre inkább illikviddé vált, a beragadt befektetők kénytelenek voltak más pozíciókat leépíteni, így a likviditási zavar gyorsan átterjedt más piacokra is. A pozíciók leépítésével párhuzamosan megindult a finanszírozási likviditás csökkenése és a tőkeáttétel leépítése. Mivel a bankok nemcsak finanszírozói, hanem aktív befektetői is voltak a piacnak, többszörös veszteségleírásra kényszerültek. A transzparencia hiánya és a bizonytalanság a bankok közötti bizalomra épülő finanszírozási piacot, a bankközi piacot is kedvezőtlenül érintette, ami a bankközi kamatok még sosem tapasztalt megugrását és a bankközi piac leállását eredményezte (Balás - Móré 2007; Nagy - Szabó 2008; PSZÁF 2013) (1. ábra). 
1. ábra

A 3 hónapos bankközi kamatláb és az $\mathrm{O} / \mathrm{N}$ index swap különbsége (felső), valamint a bankközi források alakulása (alsó) a 2008-as válságot megelőzően és azt követően
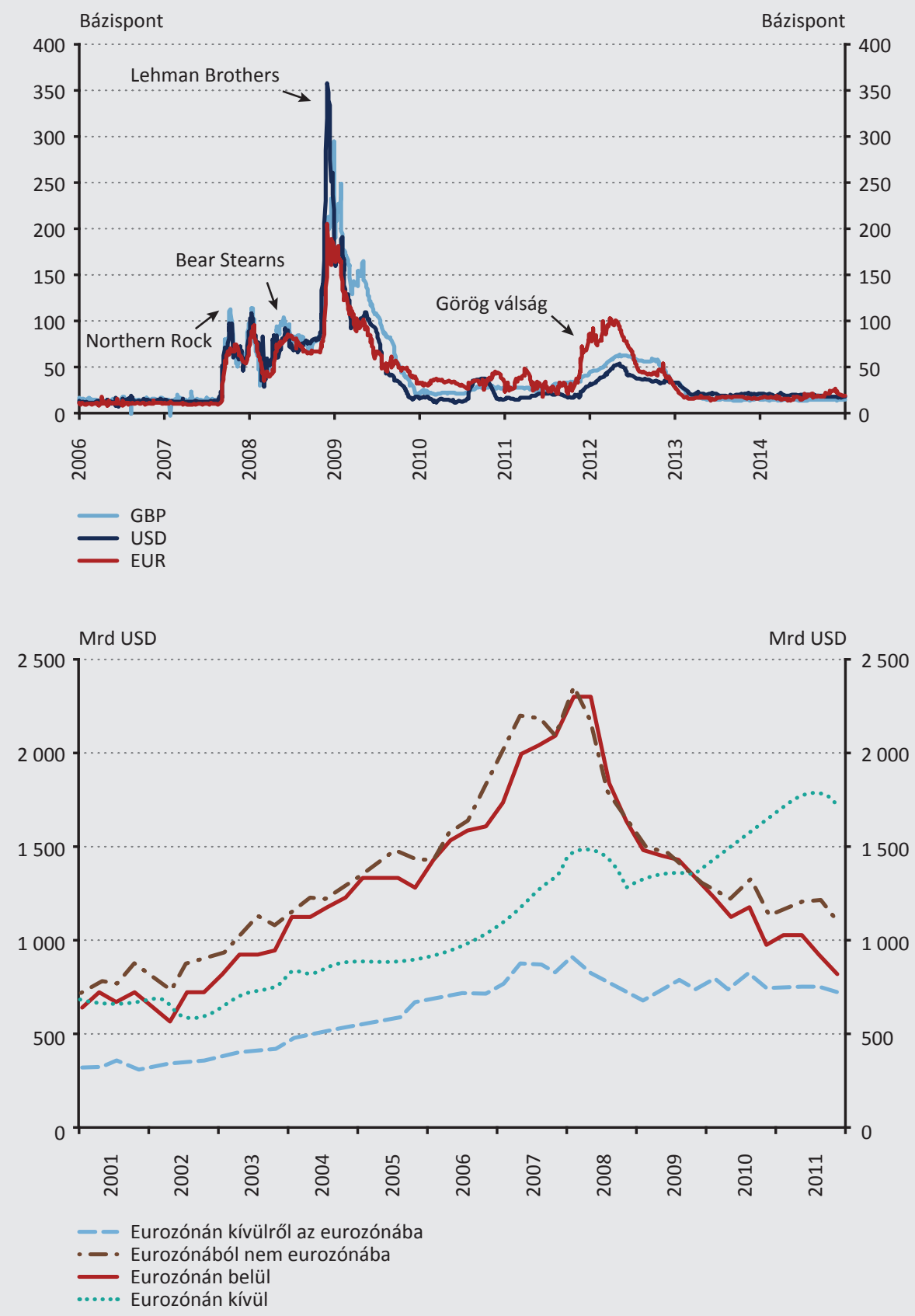

Forrás: Bloomberg, BIS International banking statistics 
A válságban fény derült arra, hogy a finanszírozási struktúrának milyen fontos szerepe van a bankok sokkellenálló képességében. A bankközi kamatok nagymértékú emelkedése és a bankközi piac kiszáradása miatt a bankközi forrásokra túlzott mértékben ráutalt bankokat sokkal mélyebben érintette a válság. Kanadára, Nagy-Britanniára és az EU országaira vonatkozóan is empirikusan igazolták, hogy a magukat kisebb mértékben ügyfélbetétekből és nagyobb mértékben bankközi forrásokból finanszírozó bankok egyértelmúen sérülékenyebbek voltak a válság során (Poghosyan - Čihák 2009; Ratnovski - Huang 2009; Yorulmazer - Goldsmith-Pinkham 2010). A nagymértékben külföldi, illetve devizaforrásokból finanszírozott rendkívüli mértékủ hitelbővülésre épülő banki üzleti modell is komoly problémákat okozott egyes országokban a válság során. Ez a gyakorlat Izlandon bankválsághoz vezetett, amikor először a nemzetközi piacokon való forrásszerzés szűkült erősen az izlandi bankok számára, majd a külföldi betétesek is elkezdték kivonni a pénzüket, ezzel mindhárom izlandi nagybank összeomlását okozva (Baudino et al. 2020).

\subsection{Kiemelt kockázatok a finanszírozásban}

\subsubsection{Devizahitelezés}

A devizahitelezés felfutása számos módon jelenthet kockázatot a pénzügyi stabilitásra. Azokban az esetekben, amikor a devizafedezettel nem rendelkező belföldi hitelfelvevő́k devizaadóssággal rendelkeznek, a belföldi fizetőeszköz leértékelődése a fennálló adósság emelkedését eredményezi, aminek következtében romlik a hitelfelvevők adósságszolgálati kapacitása. Mivel a belföldi árfolyam leértékelődése a külföldi hitellel rendelkező magánszektor nagy részét ugyanabban az időben érinti hátrányosan, egy jelentős árfolyam-leértékelődés az egész gazdaságot érintő, rendszerszintű pénzügyi stabilitási kockázatot jelenthet (ECB 2010). Mindemellett a hitelfelvevők nemteljesítési kockázatát tovább súlyosbíthatja, ha a külföldi fizetőeszköz felértékelődése a külföldi kamatok emelkedésével párosul, különösen a változó kamatozású hitelek hitelállományból való magas részesedése esetén ( $B C B S$ 2009; Hartmann 2010).

A devizahitel-portfólió minőségének jelentős romlása a kamatjövedelem számottevő csökkenése, a banki veszteségleírások és céltartalékok emelkedése révén a bankokat jelentős jövedelmezőségi kockázatnak teheti ki. Emellett a devizahitel-portfólió romlása finanszírozási kockázatot is jelenthet a bankok számára. A saját forrásaik visszafizetésére fenntartott pénzeszközeik jelentősen csökkenhetnek a hiteltörlesztések visszaesése vagy akadozása miatt. Így a bankok lejáró forrásaikat egyre nehezebben tudják visszafizetni. Ezzel megnő a bank forrásigénye és a források megújításának szükséglete, aminek kielégítését nehezebbé teheti a finanszírozók bizalmának megingása a devizahitel-portfólióhoz köthető veszteségek miatt. Ezenfelül többlet-finanszírozási kockázatot jelent, ha a bankok eltérő devizájú forrásokból finanszírozzák a devizahitelezést, devizaswap útján fedezve a devizális eltérést. Ebben az esetben, ha a likviditás számottevően lecsökken a devizaswap-piacon és 
a bankok nem férnek hozzá a központi bank devizalikviditást nyújtó eszközeihez, a devizahitelek finanszírozási kockázata már rövid távon jelentkezik (ECB 2010). Egy esetleges árfolyamgyengülés további kockázatot hordoz, hiszen ekkor a swapon jelentkező veszteség azonnal fellép, míg a devizahitelek forintban megnövekedett törlesztőrészletei miatt megemelkedett beáramlások beérkezése hosszabb időt vesz igénybe.

\subsubsection{Rövid külső adósság}

A gazdaság finanszírozási szerkezetén belül dominánssá váló külső források nagymértékben növelhetik a gazdaság sérülékenységét. Tőkehiányos gazdaságokban természetszerúleg jelentkezik igény a külső források bevonására, különösen, ha azok kedvezőbb feltételek mellett érhetők el, mint a belföldi és hazai fizetőeszközben denominált források. Piaci turbulenciák idején a külső finanszírozásra való ráutaltság legjelentősebb hátránya a megújítási kockázat, válságok esetén ugyanis a külföldi források jelentősen megdrágulhatnak vagy hirtelen elapadhatnak (Fábián - Vonnák 2014). Ez a kockázat különösen a rövid lejáratú kötelezettségek esetén jelentős. A külső megtakarításokra és a devizapiacra való ráutaltság felerősíti az árfolyam volatilitását és emeli a kamatfelárakra vonatkozó várakozásokat, amelyek válság bekövetkezése esetén alááshatják a gazdaság forrásszerzési lehetőségeit. A 2008-as globális pénzügyi válság megmutatta a külső sérülékenység kockázatait és, ebből adódóan, a nemzetközi devizatartalékok jelentőségét (Nagy - Palotai 2014; Csávás 2015).

\subsubsection{Bankközi finanszírozás}

A pénzügyi vállalatoktól származó forrásokra való túlzott ráutaltság jelentős rendszerkockázatot hordozhat, és annak esetleges materializálódása súlyos következményekkel járhat a pénzügyi rendszerben és a reálgazdaságban is. Egy magas megtakarítási képességgel és hajlandósággal jellemezhető gazdaságban a bankok elsődleges finanszírozási forrását a háztartások, valamint a kis- és középvállalkozások bankbetétei (ún. core-források) jelentik. Ugyanakkor a hitelciklus felívelő szakaszában, amikor a hitelkereslet gyorsabban növekszik, mint a rendelkezésre álló ügyfélbetétek állománya, a bankok alternatív finanszírozási forrásokat (ún. non-core-kötelezettségeket) keresnek a már említett core-források kiegészítésére a hitelnövekedés fenntartásához (Hahm et al. 2013). A rövid távú finanszírozási források széles körű elterjedése növeli a források megújítási kockázatát (Dudley 2014). Az alternatív finanszírozást nyújtó pénzügyi intézmények bizonytalanság esetén forrásokat vonhatnak ki a piacról, amivel elégtelen likviditási helyzetet idézhetnek elő (Huang - Ratnovski 2011). A fertőzéstől való félelem a bankközi hitelezés viszszaesését, ezáltal a hitelpiac összeomlását okozhatja (lyer-Peydró 2011). 


\subsubsection{Mérlegen kívüli finanszírozás}

A bankrendszer mérlegében megfigyelhető denominációs eltérés túlzott mértéke a devizaárfolyamok változásával összefüggő árfolyamkockázat miatt növeli a bankrendszer mérlegen kívüli instrumentumokra (devizaswapok) való ráutaltságát, ami rendszerszintű kockázatok kialakulásához vezethet. A hosszú lejáratú swapok esetében a letéti követelmények változása jelenti a fő kockázatot. Ezek összege az árfolyam esetleges romlása esetén érdemben megnő, ezáltal további devizakeresletet generálva tovább növelik a külső sérülékenységet és a swap-piaci ráutaltságot. Rövid távú swap-ügyleteknél további kockázatot jelent a swapokkal fedezett, jellemzően hosszú devizahitelekhez képest rövidebb futamidő: ilyenkor a megújítás kockázata is jelentős, mivel ennek elmaradása esetén a banknak nyitott devizapozíciója alakul ki, és az azonnali piacon kell devizaforráshoz jutnia (Páles et al. 2010). A rövid távú ügyletek esetében a swap-piac kiszáradása főként azért jelent érdemi veszélyt, mert a lejáró devizaswap-ügylet deviza lábának visszafizetéséhez szükséges deviza beszerzése az azonnali piacon annak a devizaswap-piacnál jelentősen kisebb volumene miatt az árfolyam gyengüléséhez vezethet. Annak a kockázata is fennáll továbbá, hogy az ilyen módon való devizaszerzés rendszerszintű szükséglet esetén nem tud megvalósulni az eltérő volumenek miatt, ez pedig ahhoz vezethet, hogy a bank nem tudja teljesíteni devizában felmerülő fizetési kötelezettségeit.

\section{A globális pénzügyi válság hazai tanulságai}

\subsection{A magyar bankrendszer a válságban}

A 2007-ben kibontakozó pénzpiaci válság rendkívül súlyosan érintette a magyar bankrendszert, annak ellenére, hogy annak sem a krízis kialakulásában, sem pedig annak tovagyűrüzésében nem volt szerepe. Az ország válság idején tapasztalt pénzügyi sérülékenysége elsősorban a bankrendszer rövid lejáratú devizafinanszírozási igényéből eredő likviditási, valamint a devizahitel-állomány következtében jelentkező szolvenciakockázatokból fakadt. A pénzügyi rendszer gyengesége és a hitelezési aktivitás visszaesése elmélyítette a recessziót és lassította a kilábalást (Nagy - Vonnák 2014).

A válság előtti sérülékenység kialakulásának okai elsősorban a 2000-es évek első felében folytatott fogyasztásösztönző gazdaságpolitika és az inflációs folyamatok miatt tartósan magas szinten alakuló nominális forintkamatokra vezethetők vissza. Mindemellett az inflációs célkövetés és az árfolyamsáv inkonzisztens monetáris rendszerében a forint euróval szembeni árfolyama szúk sávban mozgott, ami egyfajta árfolyamstabilitási érzetet nyújtott, és az árfolyamkockázat alulbecsléséhez vezetett. A háztartások korábban elhalasztott fogyasztási kereslete és az optimista jövedelemvárakozások a devizahitelek iránti kereslet felfutásához vezettek (Nagy - Vonnák 2014). 
A devizahitelezés felfutása a kockázatok növekedésével járt együtt, mivel a hitelkihelyezésben folyó versenyben a bankok fokozatosan lazították a hitelkondícióikat. Ez az üzleti modell a válságot megelőző években egyre egészségtelenebbé vált, a bankok a hitelezés finanszírozása során egyre nagyobb mértékben támaszkodtak külföldi, nagyrészt rövid lejáratú, döntően bankközi források bevonására, valamint devizaswapokra. Az expanzív gazdaságpolitika és a hazai bankrendszer devizahitelezési gyakorlata tehát kockázatos lakossági és vállalati hitelezéshez vezetett. A helyzetet tovább súlyosbította a szabályozó hatóságok tétlensége, mivel a makroprudenciális feladatkörök és jogosítványok intézményi leosztása nem volt tisztázott (Fábián Vonnák 2014).

A válság előtt a bankok a devizahitelezés egy részét belföldi devizában vagy más külföldi devizában denominált forrásokból finanszírozták, így a mérleg szerinti devizapozíciójuk egy részét devizaswap-ügyletek segítségével zárták. A pénzügyi válság kirobbanása után azonban jelentősen nehezebb lett devizalikviditáshoz jutni, szűkültek a partnerlimitek, valamint megnőtt a forint árfolyamának volatilitása. A hazai devizaswap-piac teljes átlagos forgalma rendkívüli mértékben ugyan nem esett vissza, de a piac likviditása néhány napra jelentősen csökkent, a devizalikviditáshoz való hozzáférés korlátozottá vált. A futamidők rövidültek, illetve az anyabankok aktív szerepvállalására is szükség volt a forgalom visszaesésének elkerülésében. Az implikált forinthozamok jelentős mértékben elszakadtak a kamatfolyosó aljától, így a nemzetközi bankközi hozamokhoz képest csak magas felár mellett lehetett devizalikviditáshoz jutni (Páles et al. 2010).

Az említett sérülékenységek alakulását kiválóan érzékelteti néhány kiemelt indikátor időbeli változása is (2. ábra). Látható, hogy a devizahitelezés banki mérlegben való térnyerése mellett elsősorban a rövid lejáratú devizaforrásokra, illetve mérlegen kívüli kockázatvállalásra hagyatkozó finanszírozási modell alakult ki a hazai bankrendszerben 2008-at megelőzően. Ez párosult egy folyamatosan szúkülő, kifeszített likviditási pozícióval, amelyet az operatív likviditási tartalék ${ }^{3}$ válság előtti alacsony és csökkenő szintje jelzett.

\footnotetext{
${ }^{3} \mathrm{~A}$ banki likvid eszközök állományából és a treasury-műveletek 30 napon belüli szerződés szerinti nettó áramlásaiból (portfólió-gap) összeálló, a banki likviditási helyzet monitorozására szolgáló mutató.
} 


\section{2. ábra \\ Kiemelt mérlegfőösszeg-arányos bankrendszeri indikátorok alakulása}

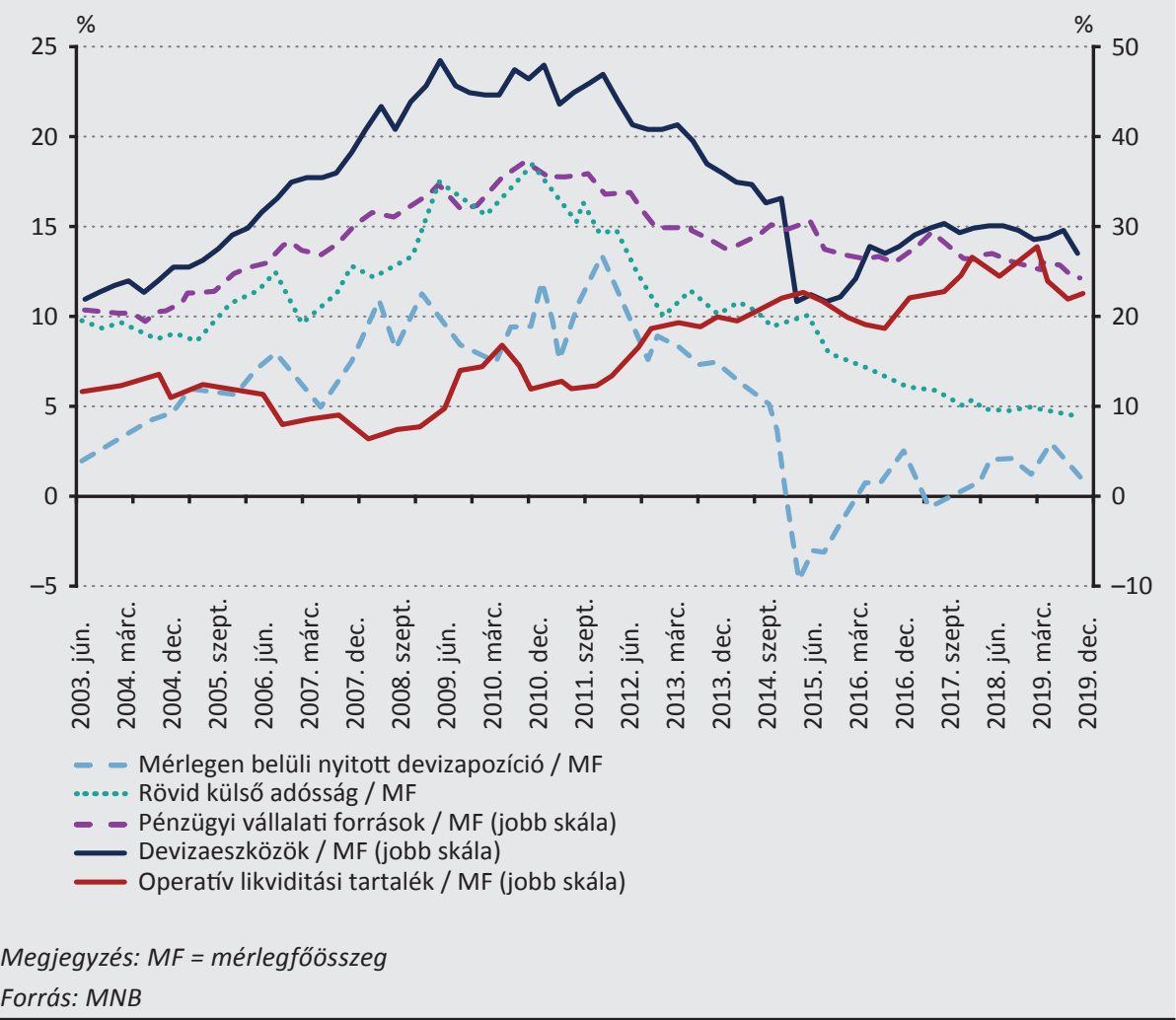

\subsection{Az MNB likviditási és finanszírozási szabályozási eszköztára}

Az Európai Unióban a makroprudenciális politika alapját 2013-tól az Egységes szabálykönyv két eleme, a CRR ${ }^{4}$ és a CRDIV ${ }^{5}$, valamint kapcsolódó jogi aktusok adják. A makroprudenciális politikát az Európai Rendszerkockázati Testület (European Systemic Risk Board, ESRB) koordinálásával elsősorban a tagországi makroprudenciális hatóságok ${ }^{6}$ alkalmazzák, múködtetik. Az EU szabályozási keretein belül elérhető eszközökön túl nemzeti hatáskörben kidolgozott eszközök alkalmazására is mód van.

\footnotetext{
${ }^{4}$ Az Európai Parlament és a Tanács 575/2013/EU Rendelete a hitelintézetekre és befektetési vállalkozásokra vonatkozó prudenciális követelményekről és a 648/2012/EU rendelet módosításáról

${ }^{5}$ Az Európai Parlament és a Tanács 2013/36/EU Irányelve a hitelintézetek tevékenységéhez való hozzáférésről és a hitelintézetek és befektetési vállalkozások prudenciális felügyeletéről, a 2002/87/EK irányelv módosításáról, a 2006/48/EK és a 2006/49/EK irányelv hatályon kívül helyezéséről

${ }^{6}$ Ez lehet a jogszabályi implementációtól függően nemzeti bank, felügyelet, minisztérium vagy akár egy független testület is.
} 
2013. október 1-jétől az Országgyúlés döntése alapján az MNB mandátumai közé került nemcsak a felügyeleti, de a szanálási és makroprudenciális funkció is. Többek között ennek is volt köszönhető, hogy egyrészt az Egységes szabálykönyv által felkínált likviditási-finanszírozási eszközök, így az LCR, a 2021. június 28-án hatályba lépő NSFR ${ }^{7}$, valamint a CRR 458. cikke szerinti nemzeti rugalmassági eszköz keretében módosítható likviditási követelményekért is az MNB lett a felelős. 2013ban továbbá az MNB olyan rendeletalkotási mandátumot kapott ${ }^{8}$, amely alapján nemzeti hatáskörben is alkothat a bankok finanszírozását célzó makroprudenciális követelményeket.

Így a 2012-ben még a felelős minisztérium közremúködésével kormányrendeletben szabályozott ${ }^{9}$ DMM kivételével egy sor szabályozást az MNB saját hatáskörében alkotott meg, amely szabályozásokra vonatkozó releváns információkat az 1. táblázat tartalmazza. Ezenkívül az EU-szinten alkalmazott LCR korai bevezetése is nemzeti hatáskör gyakorlása nyomán történt meg. A felsorolt eszközök nem igényeltek a bankoktól nagymértékű alkalmazkodást a pénzügyi ciklus alján való bevezetésük miatt, így preventíven a jövőbeli kockázatok felépülésének megakadályozását célozzák.

1. táblázat

Az MNB általi likviditási és finanszírozási szabályozások bevezetésének és felülvizsgálatának historikus áttekintése

\begin{tabular}{l|c|l} 
& Hatályba lépés & \multicolumn{1}{c}{ Tartalma } \\
\hline $\begin{array}{l}\text { DMM } \\
\text { bevezetése* }\end{array}$ & 2012. július 1. & $\begin{array}{l}\text { Egy NSFR típusú, a speciális hazai likviditási kockázatok } \\
\text { sajátosságait figyelembe vevő, a devizakockázatot, illetve az } \\
\text { eszközök és források lejárati eltérésből adódó kockázatot kezelő } \\
\text { szabályozás bevezetése, 65 százalékos minimumszint } \\
\text { elvárásával }\end{array}$ \\
\hline $\begin{array}{l}\text { Betét- és } \\
\text { mérlegfedezeti } \\
\text { mutató } \\
\text { bevezetése* }\end{array}$ & 2012. július 1. & $\begin{array}{l}\text { Rövid lejáratú, 30 napos likviditási kockázatokat kezelő } \\
\text { szabályozások bevezetése }\end{array}$ \\
\hline $\begin{array}{l}\text { DMM 1. } \\
\text { felülvizsgálata }\end{array}$ & 2014. július 1. & $\begin{array}{l}\text { MNB-rendeletként való előírás, fokozatosan szintbéli szigorítás } \\
\text { és az intézményi hatály kiterjesztése az EU-s fióktelepekre is }\end{array}$ \\
\hline $\begin{array}{l}\text { Betét- és } \\
\text { mérlegfedezeti } \\
\text { mutató } \\
\text { kivezetése }\end{array}$ & 2015. szeptember 30. & $\begin{array}{l}\text { A szabályozásoknak az LCR bevezetése miatt történő hatályon } \\
\text { kívül helyezése }\end{array}$ \\
\hline
\end{tabular}

\footnotetext{
${ }^{7}$ Az NSFR bevezetéséről a felülvizsgált CRR, a CRR2 rendelkezik: AZ Európai Parlament és a Tanács (EU) 2019/876 Rendelete (2019. május 20.) az 575/2013/EU rendeletnek a tőkeáttételi mutató, a nettó stabil forrásellátottsági ráta, a szavatolótőkére és a leírható, illetve átalakítható kötelezettségekre vonatkozó követelmények, a partnerkockázat, a piaci kockázat, a központi szerződő felekkel szembeni kitettségek, a kollektív befektetési formákkal szembeni kitettségek, a nagykockázat-vállalások és az adatszolgáltatási és nyilvánosságra hozatali követelmények tekintetében történő módosításáról, valamint a 648/2012/EU rendelet módosításáról

${ }^{8}$ 2013. évi CXXXIX. törvény a Magyar Nemzeti Bankról

${ }^{9}$ A 2012. július 1-jén bevezetett DMM, BFM és MFM mutatókat az MNB rendeletalkotási jogosítványának hiányában még MNB-javaslatra a kormány szabályozta.
} 


\section{1. táblázat (folytatás)}

\section{Az MNB általi likviditási és finanszírozási szabályozások bevezetésének és felülvizsgálatának historikus áttekintése}

\begin{tabular}{|c|c|c|}
\hline $\begin{array}{l}\text { LCR } \\
\text { bevezetése** }\end{array}$ & 2015. október 1. & Az EU-jogszabályok szerint induló LCR-bevezetés 60 százalékon \\
\hline $\begin{array}{l}\text { DMM } 2 . \\
\text { felülvizsgálata }\end{array}$ & 2016. január 1. & $\begin{array}{l}\text { Az elvárt szint } 100 \text { százalékra emelése és az éven túli nettó } \\
\text { devizaswap-állomány kizárása a stabil devizaforrások közül }\end{array}$ \\
\hline $\begin{array}{l}\text { DEM } \\
\text { bevezetése }\end{array}$ & 2016. január 1. & $\begin{array}{l}\text { A mérlegen belüli devizális eltérést maximáló, a bankok } \\
\text { devizaswap-piacra való túlzott ráutaltságát limitáló szabályozás } \\
\text { bevezetése } 15 \text { százalékos maximumszint elvárásával }\end{array}$ \\
\hline $\begin{array}{l}\text { LCR } 1 . \\
\text { módosítása** }\end{array}$ & 2016. január 1. & $\begin{array}{l}\text { Fokozatos bevezetéssel összefüggő szintemelés ( } 70 \text { százalék) az } \\
\text { EU jogszabályi ütemtervével összhangban }\end{array}$ \\
\hline $\begin{array}{l}\text { LCR nemzeti } \\
\text { diszkréció }\end{array}$ & 2016. április 1. & $\begin{array}{l}\text { Nemzeti hatáskörben a követelmény átmeneti időszakának } \\
\text { lerövidítése és a } 100 \text { százalékos megfelelés azonnali elvárásával } \\
\text { összefüggő szigorítás }\end{array}$ \\
\hline $\begin{array}{l}\text { JMM } \\
\text { bevezetése }\end{array}$ & 2016. október 1. & $\begin{array}{l}\text { Forint lejárati összhang növelését hosszú lejáratú, jelzálogalapú } \\
\text { források bevonásán keresztül ösztönző szabályozás bevezetése } \\
15 \text { százalékos minimumszint elvárásával }\end{array}$ \\
\hline $\begin{array}{l}\text { JMM } 1 . \\
\text { felülvizsgálata }\end{array}$ & 2017. április 1. & Bevezetés halasztása az új zálogjogi szabályozásokra tekintettel \\
\hline $\begin{array}{l}\text { DMM } 3 . \\
\text { felülvizsgálata }\end{array}$ & 2018. július 1. & $\begin{array}{l}\text { A forintosítást követően megváltozott banki mérlegszerkezetek } \\
\text { és finanszírozási üzleti modellek, valamint az NSFR-hez való } \\
\text { további közelítés érdekében történt felülvizsgálat }\end{array}$ \\
\hline $\begin{array}{l}\text { BFM } \\
\text { bevezetése }\end{array}$ & 2018. július 1. & $\begin{array}{l}\text { A bankok pénzügyi vállalatoktól származó forrásokra való } \\
\text { túlzott ráutaltságát és az ebből eredő rendszerkockázatokat } \\
\text { korlátozó szabályozás bevezetése }\end{array}$ \\
\hline $\begin{array}{l}\text { JMM } 2 . \\
\text { felülvizsgálata }\end{array}$ & 2018. október 1. & $\begin{array}{l}\text { Elvárt szintbeli ( } 20 \text { százalék) és a bevonható források minőségét } \\
\text { érintő szigorítás }\end{array}$ \\
\hline $\begin{array}{l}\text { JMM } 3 . \\
\text { felülvizsgálata }\end{array}$ & $\begin{array}{l}\text { 2019. február } 1 . \\
\text { és } \\
\text { 2019. október } 1 \text {. }\end{array}$ & $\begin{array}{l}\text { Elvárt szintbeli ( } 25 \text { százalék), valamint a de minimis limitet és } \\
\text { a bevonható források minőségét érintő szigorítás }\end{array}$ \\
\hline $\begin{array}{l}\text { JMM } 4 . \\
\text { felülvizsgálata }\end{array}$ & 2020. március 24. & $\begin{array}{l}\text { A koronavírus hatásaival összefüggő enyhítés, } \\
\text { a keresztfinanszírozási korlátozások felfüggesztése }\end{array}$ \\
\hline $\begin{array}{l}\text { DMM } 4 . \\
\text { felülvizsgálata }\end{array}$ & 2020. március 24. & $\begin{array}{l}\text { A koronavírus hatásaival összefüggő likviditási } \\
\text { kockázatnövekedés miatti szigorítás }\end{array}$ \\
\hline $\begin{array}{l}\text { DEM } 1 . \\
\text { felülvizsgálata }\end{array}$ & 2020. március 24. & $\begin{array}{l}\text { A koronavírus hatásaival összefüggő likviditási } \\
\text { kockázatnövekedés miatti szigorítás }\end{array}$ \\
\hline $\begin{array}{l}\text { DMM } 5 . \\
\text { felülvizsgálata }\end{array}$ & 2020. szeptember 18. & $\begin{array}{l}\text { A koronavírus hatásaival összefüggő átmeneti szigorítás } \\
\text { kivezetése }\end{array}$ \\
\hline $\begin{array}{l}\text { DEM } 2 . \\
\text { felülvizsgálata }\end{array}$ & 2020. szeptember 18 . & $\begin{array}{l}\text { A koronavírus hatásaival összefüggő átmeneti szigorítás } \\
\text { kivezetése }\end{array}$ \\
\hline
\end{tabular}

Megjegyzés: *Az MNB makroprudenciális mandátumának hiányában az MNB-vel együttmüködve Kormányrendelet vezette be. ** Közvetlenül hatályos EU rendelet írta elő.

Forrás: $M N B$ 
2018-ra egy olyan eszköztár állt fel a likviditási és finanszírozási kockázatok csökkentésére, illetve megelőzésére, amelynek elemei egymást kiegészítve a válság előtt felépült rendszerkockázatokra - korai bevezetés esetén - érdemi hatással bírhattak volna. A következőkben azonban csak azokat a követelményeket ismertetjük, amelyek a visszatesztelési gyakorlatunk szempontjából relevánsak, vagyis leginkább hatással vannak a rövid lejáratú külső finanszírozással és a devizahitelezéssel kapcsolatos kockázatok alakulására ${ }^{10}$.

- Likviditásfedezeti mutató: A likviditásfedezeti követelmény elvárja, hogy megfelelő mennyiségú és minőségú likvid eszköz álljon a bankok rendelkezésére egy esetleges rövid távú (30 napos) likviditási sokk esetén feltételezhető nettó kiáramlás fedezetére. A likviditásfedezeti követelmény teljesítése alapvetően a magas likviditású eszközök állományának növelésén, illetve a hosszabb lejáratú források bevonásán keresztül mehet végbe.

\section{LCR = Likvid eszközök / Nettó likviditáskiáramlás > 100\%}

- Devizafinanszírozás megfelelési mutató: Az egyes intézmények stabil finanszírozást igénylő devizaeszközeihez (főként hosszú lejáratú, illikvid devizaeszközök) igazodva várja el megfelelő mennyiségú stabil devizaforrás tartását. A szabályozás hatásmechanizmusa kettős. Egyrészt az előírás hatására a mérlegen belüli denominációs eltérésből eredő kockázatok csökkennek, és a mérlegen kívüli kötelezettségnövekedés korlátozódik. Másrészt a devizaforrások közül a stabil, hosszú lejáratú finanszírozást megtestesítő források igénybevételére ösztönöz, ezáltal csökkentve a hitelintézetek mérlegében található lejárati eltérést. A DMM hathat ezenkívül a mérlegen kívüli garanciavállalásokra is. Egyéb eszközökkel, például a DEM-mel kiegészítve a bankrendszer külső sérülékenységét is mérsékelheti.

DMM = Stabil devizaforrások súlyozott összege / Stabil devizaforrás igény > 100\%

- Devizaegyensúly mutató: A szabályozás az eszközök és források közötti denominációs eltérés mértékét maximálja a mérlegfőösszeg arányában. Mivel csökken a mérlegen belüli denominációs eltérés mértéke, mérséklődik az intézmények mérlegen kívüli instrumentumokra, főként devizaswapokra való ráutaltságának mértéke is, ami az ezen instrumentumokból eredő - megújítási, likviditási és margin call - kockázatokat is csökkenti. Más eszközökkel, például a DMM-mel együtt

\footnotetext{
${ }^{10}$ A rövid lejáratú likviditási kockázatokat célzó és az LCR bevezetésével hatályon kívül helyezett betétfedezeti és mérlegfedezeti mutatók, valamint a forint lejárati összhang biztosítását szolgáló jelzáloghitelfinanszírozás megfelelési mutató (JMM) ismertetésétől eltekintünk, mivel a szabályozásokat nem szerepeltetjük a visszatesztelési gyakorlatban. Mivel az LCR bevezetésével hatályon kívül helyezett eszközök az LCRelőírással megegyező kockázatokat kezeltek, ezért elegendőnek láttuk az LCR szerepeltetését az elemzésben. A JMM a forintosítást követően, a hosszú forint-jelzáloghitelek bankok mérlegében való nagy volumenú megjelenésével emelkedő forint lejárati eltérést kívánja kezelni, amely kockázat a forint-jelzáloghitelek kisebb mértéke és a jelzáloglevelek nagyobb állománya miatt a válság előtt nem volt jelentős.
} 
az eszköz megfelelően kezelheti a külső finanszírozás sérülékenységéből eredő kockázatokat is.

$$
D E M=A B S\left(\text { Devizaeszközök - Devizaforrások) } / \text { Mérlegföösszeg }<15 \%{ }^{11}\right.
$$

- Bankközi finanszírozási mutató: A szabályozás a pénzügyi vállalatoktól származó források devizanem és hátralévő lejárat szerint súlyozott összegét korlátozza a külső kötelezettségek arányában. A célzott intézkedés hatékonyan előzheti meg a pénzügyi vállalatoktól származó forrásokra való túlzott ráutaltság kialakulását.

$$
\begin{gathered}
\text { BFM = Pénzügyi vállalatoktól származó források súlyozott összege / } \\
\text { (Mérlegföösszeg - Saját tőke }<30 \%
\end{gathered}
$$

A szabályozások összességében a banki mérleg gyakorlatilag teljes egészére képesek hatást kifejteni, egy-egy specifikus finanszírozási, likviditási aspektust ragadva meg, de egymást jól kiegészítve (3. ábra).

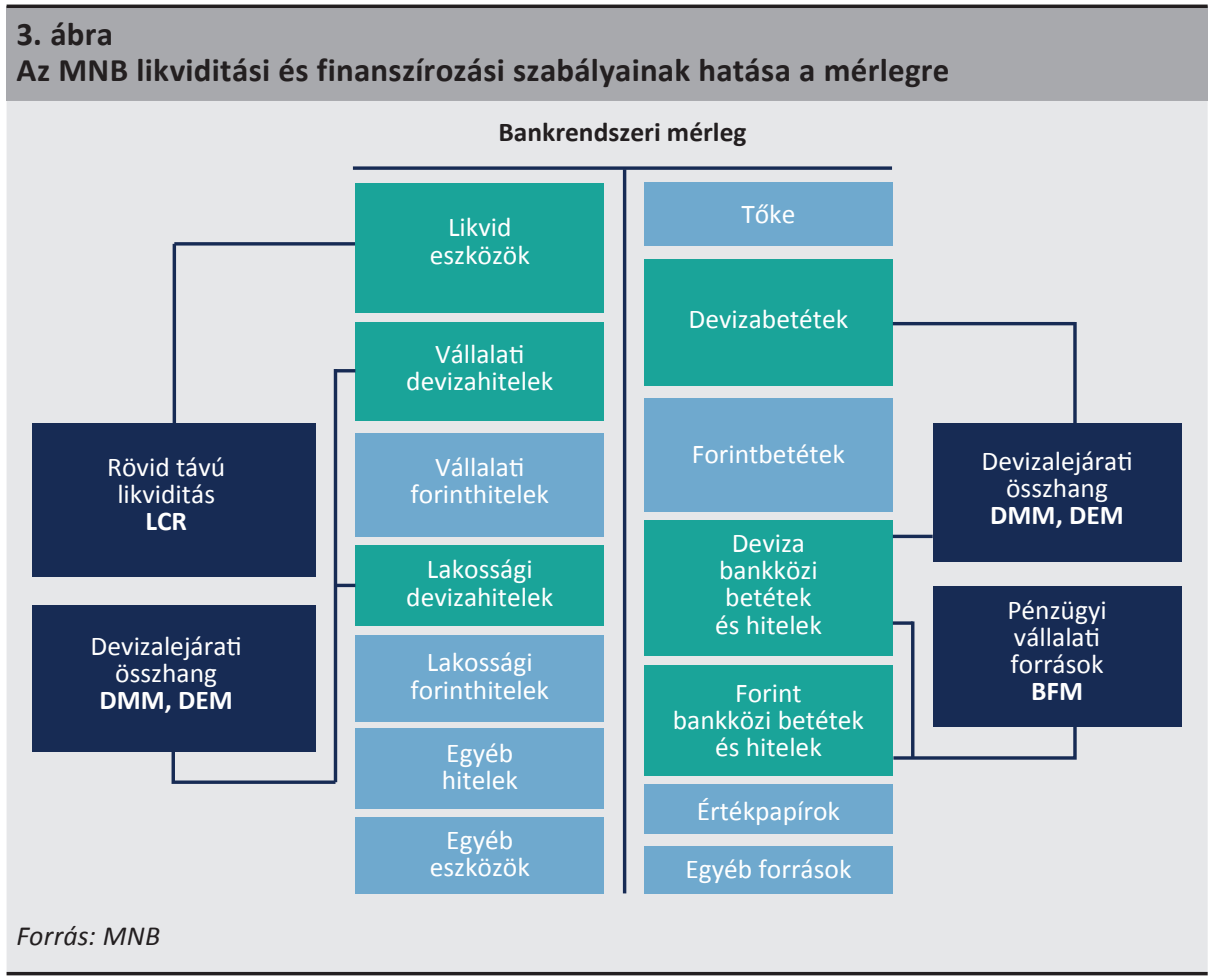

${ }^{11}$ A koronavírus-járvány következtében növekvő kockázatok miatt 2020. március 24-től 2020. szeptember 17-ig a megengedett szint átmenetileg 10 százalékra csökkent. 


\section{Egyes likviditási és finanszírozási szabályozások visszatesztelésének módja}

\subsection{Módszertan}

A kiválasztott likviditási és a devizalejárati eltérés különböző dimenzióit megragadó finanszírozási szabályok válság előtti bevezetése esetén az érintett intézményeknek, amennyiben még nem feleltek meg a követelményeknek, alkalmazkodniuk kellett volna a megfelelés érdekében. A legnagyobb módszertani kihívást az jelenti, hogy visszamenőleg nincs lehetőségünk pontosan meghatározni, hogy a vizsgált bankok milyen alkalmazkodási csatornát választottak volna. Ebben azok a sztochasztikus modellek sem kínálnak megoldást, amelyeket gyakran alkalmaznak szabályozói intézkedések értékeléséhez, teszteléséhez. Ezek a modellek (mint a difference in differences, propensity score matching és a synthetic control method) kontroll- és kezelt csoportokat identifikálnak, majd ezek egymáshoz viszonyított dinamikáját azonosítják a beavatkozás hatásaként. A makroprudenciális keretrendszer bevezetése azonban az egész magyar bankrendszert egységesen érintette, így nem lehetséges megfelelő kontrollcsoport azonosítása. Emellett a nemzetközi kitekintés haszna is minimális lenne, mivel a legkorábbi, általunk vizsgált időszak a makroprudenciális keretrendszer 2003-as bevezetését feltételezi. Ebben az időszakban még más országokban sem merült fel átfogó makroprudenciális politika, dedikáltan makroprudenciális eszközök bevezetése és alkalmazása, így olyan viszonyítási alapot nem lehet találni, amihez a magyar bankrendszer változásait hasonlíthatnánk.

Ezeket a problémákat megkerülve, egy teljes egészében determinisztikus megközelítést alkalmazunk: egy sor feltevéssel élünk, amelyek jól közelítik a bankrendszer igazodási lehetőségeit. Mivel nincs rá módunk, hogy pontosan meghatározzuk, hogy az egyes bankok miként reagáltak volna a fent felsorolt szabályozásokra, magunk gyújtjük össze a leginkább megvalósítható és költséghatékony lehetőségeket. Természetesen nem gondoljuk, hogy minden vizsgált bank az általunk meghatározott alkalmazkodást választotta volna - mindössze arra törekedtünk, hogy rendszerszinten jól közelítsük a leghatékonyabb alkalmazkodási lehetőségeket. Fontosnak tartjuk tehát megjegyezni, hogy az így számolt értékek csak hozzávetőleges képet adnak a vizsgált szabályrendszer hatásairól.

Lehetséges egyszerű, nagymértékű mutatójavulást eredményező és mérlegkorlátokkal kevésbé akadályozott alkalmazkodási módokat definiáltunk, és szakértői alapon rangsoroltuk azokat kivitelezhetőség és költségesség szerint. Az alkalmazkodás a rangsor alapján történik úgy, hogy a bankok az első helyre sorolt alkalmazkodási móddal a releváns korlát eléréséig alkalmazkodnak, majd áttérnek a rangsorban következő alkalmazkodási módra. Az alkalmazkodás addig zajlik, amíg meg nem fe- 
lelnek az összes mutatóra vonatkozó követelménynek, illetve amíg az előre definiált alkalmazkodási módokkal képesek javítani a mutatóikon. Bár a sorrend meghatározásakor igyekeztünk minden szempontot kellő körültekintéssel figyelembe venni, annak érdekében, hogy a szakértői alapú rangsorolásból fakadó bizonytalanságokat minimalizáljuk, azokra az eredményekre koncentrálunk, amelyek nem, vagy csak kismértékben függenek az általunk meghatározott sorrendtől. A mutatókhoz történő alkalmazkodás vizsgálatához - a DMM kivételével ${ }^{12}$ - a koronavírus-járvány miatti átmeneti módosítást megelőzően hatályos előírásokat vettük alapul.

A finanszírozási mutatóknak való megfelelés érdekében a forrásszerkezet átalakításával forrásoldalon, vagy a devizahitelezés leépítésével eszközoldalon alkalmazkodni kényszerültek volna a bankok. Két esetet különböztettünk meg aszerint, hogy a bankok képesek-e korlát nélkül a forrásoldalon alkalmazkodni, vagy szükség van-e a devizahitel-állomány leépítésére is. Az első esetben, amikor kizárólag forrásoldali alkalmazkodásról beszélünk, a bankok a devizális és lejárati összhang növelése érdekében stabil devizaforrásaik mértékét növelik meglévő forrásaik devizára váltásával, meghosszabbításával vagy új hosszú devizaforrások bevonásával (2. táblázat). Ebben az esetben azt feltételeztük, hogy az A4 módnak, vagyis a hosszú devizaforrás bevonásának nincs korlátja.

Az alkalmazkodás menete és hatása a mutatókra, amelyet a 2. táblázat mutat be, a következő: az A1 alkalmazkodás esetében 100 forint 1-2 éves futamidő közötti forint bankközi külső forrás devizára váltása a BFM számlálóját 10 forinttal növeli a devizaforrások kedvezőtlenebb súlyozása miatt, ezzel kismértékben rontva a mutató mértékét. Emellett ugyanakkor a DMM és a DEM értékét ez a múvelet javítja, a DMM számlálóját 100 forinttal emelve, illetve a DEM számlálóját 100 forinttal csökkentve. Ezt az alkalmazkodást addig végzi a bank, ameddig minden mutatónak sikerül megfelelnie, vagy ameddig marad még fenn 1-2 éves futamidő közötti forint bankközi külső forrása. Ha már nem áll rendelkezésre ilyen forrása, de még nem sikerült minden mutatónak megfelelnie, akkor a sorrendben következő (A2) alkalmazkodást kezdi el.

${ }^{12}$ A DMM esetében a 2018. július 1-jét megelőzően hatályban lévő DMM-mel számoltunk, tekintettel az akkori DMM könnyebb visszabecsülhetőségére. 


\begin{tabular}{|c|c|c|c|c|c|c|}
\hline \multicolumn{7}{|c|}{$\begin{array}{l}\text { A kizárólag forrásoldali alkalmazkodás esetén alkalmazott alkalmazkodási módok, } \\
\text { azok feltételezett sorrendje, valamint a mutatókra kifejtett hatásuk }\end{array}$} \\
\hline \multicolumn{3}{|c|}{ ALKALMAZKODÁSI MÓD } & \multicolumn{4}{|c|}{ ALKALMAZKODÁSI MÓD HATÁSA A MUTATÓKRA } \\
\hline AM & Eszköz & Forrás & BFM & DMM & DEM & LCR $^{*}$ \\
\hline $\mathrm{A} 1$ & Nincs & $\begin{array}{l}\text { 1-2 éves forint } \\
\text { bankközi külsó } \\
\text { forrás devizára } \\
\text { váltása }\end{array}$ & $\begin{array}{l}\text { Számláló } \\
\text { 个10\% }\end{array}$ & $\begin{array}{l}\text { Számláló } \\
\text { 个100\% }\end{array}$ & $\begin{array}{l}\text { Számláló } \\
\downarrow 100 \%\end{array}$ & 0 \\
\hline$A 2$ & Nincs & $\begin{array}{l}2 \text { éven túli forint } \\
\text { bankközi külső } \\
\text { forrás devizára } \\
\text { váltása }\end{array}$ & 0 & $\begin{array}{l}\text { Számláló } \\
\text { 个100\% }\end{array}$ & $\begin{array}{l}\text { Számláló } \\
\downarrow 100 \%\end{array}$ & 0 \\
\hline A3 & Nincs & $\begin{array}{l}\text { 0-1 éves deviza } \\
\text { bankközi külső } \\
\text { forrás } 2 \text { éven túlra } \\
\text { hosszítása }\end{array}$ & $\begin{array}{l}\text { Számláló } \\
\downarrow 100 \%\end{array}$ & $\begin{array}{l}\text { Számláló } \\
\text { 个100\% }\end{array}$ & 0 & 0 \\
\hline A4 & $\begin{array}{l}\text { Forint } \\
\text { állampapír } \\
\text { vásárlása }\end{array}$ & $\begin{array}{l}2 \text { éven túli deviza } \\
\text { külső bankközi } \\
\text { forrás bevonása }\end{array}$ & $\begin{array}{l}\text { Nevező } \\
\text { 个100\% }\end{array}$ & $\begin{array}{c}\text { Számláló } \\
\text { 个100\% }\end{array}$ & $\begin{array}{l}\text { Számláló } \\
\downarrow 100 \% \\
\text { Nevező } \\
\uparrow 100 \%\end{array}$ & $\begin{array}{c}\text { Számláló } \\
\text { 个100\% }\end{array}$ \\
\hline \multicolumn{7}{|c|}{$\begin{array}{l}\text { Megjegyzés: *Ki- és beáramlási vonzatok pontos becslése, ahol releváns lenne, nem megoldható, az } \\
\text { LCR-mutató változásában csak a likvid eszközök állományának változása jelenik meg. Továbbá az egyes } \\
\text { alkalmazkodási módok esetében az oszlopokban az adott indikátorra kifejtett hatás látható az alkalmaz- } \\
\text { kodás mértékének százalékában, vagyis az, hogy egységnyi alkalmazkodás milyen mértékben módosítja } \\
\text { a mutatók számlálóját vagy nevezójét, igy rontva vagy javittva a szabályozásnak való megfelelést. Piros } \\
\text { háttérrel a mutató romlását, zölddel a javulását jeleztük, DEM esetén pozitív kiinduló értéket felté- } \\
\text { telezve. }\end{array}$} \\
\hline
\end{tabular}

A második esetben, amikor már eszközoldali alkalmazkodással is számolunk, az A4 módnak, vagyis a hosszú devizaforrás bevonásának lehetősége korlátozott, hiszen feltételezhető, hogy a hazai bankok nem tudnak végtelen mennyiségben devizaforrást bevonni. Feltételezésünk szerint csak feleannyi forráshoz tudnak hozzájutni a bankok, mint az az első esetben szükséges volt, ezért eszközoldali, a devizahitel-állományt is érintő alkalmazkodás szükségessége is felmerül (3. táblázat). A devizahitel-állomány leépítése a feltételezésünk szerint az állomány forintosítása útján történne. 


\begin{tabular}{|c|c|c|c|c|c|c|}
\hline \multirow{2}{*}{\multicolumn{3}{|c|}{$\begin{array}{l}\text { 3. táblázat } \\
\text { Forrás- és eszközoldali alkalmazkodás } \\
\text { sorrendje, valamint a mutatókra kifejt } \\
\qquad \text { ALKALMAZKODÁSI MÓD }\end{array}$}} & \multirow{2}{*}{\multicolumn{4}{|c|}{ ALKALMAZKODÁSI MÓD HATÁSA A MUTATÓKRA }} \\
\hline & & & & & & \\
\hline AM & Eszköz & \multirow{2}{*}{\begin{tabular}{|l|}
\multicolumn{1}{|c|}{ Forrás } \\
1-2 éves forint \\
bankközi külső forrás \\
devizára váltása \\
\end{tabular}} & \multirow{2}{*}{$\begin{array}{c}\text { BFM } \\
\text { Számláló } \\
\text { 个10\% }\end{array}$} & \multirow{2}{*}{$\begin{array}{c}\text { DMM } \\
\text { Számláló } \\
\text { 个100\% }\end{array}$} & \multirow{2}{*}{\begin{tabular}{|c|} 
DEM \\
Számláló \\
$\downarrow 100 \%$
\end{tabular}} & LCR $^{*}$ \\
\hline A1 & Nincs & & & & & 0 \\
\hline A2 & Nincs & $\begin{array}{l}2 \text { éven túli forint } \\
\text { bankközi külső forrás } \\
\text { devizára váltása }\end{array}$ & 0 & $\begin{array}{l}\text { Számláló } \\
\text { 个100\% }\end{array}$ & $\begin{array}{l}\text { Számláló } \\
\downarrow 100 \%\end{array}$ & 0 \\
\hline A3 & Nincs & $\begin{array}{l}\text { 0-1 éves deviza } \\
\text { bankközi külső } \\
\text { forrás } 2 \text { éven túlra } \\
\text { hosszítása }\end{array}$ & $\begin{array}{l}\text { Számláló } \\
\downarrow 100 \%\end{array}$ & $\begin{array}{l}\text { Számláló } \\
\text { 个100\% }\end{array}$ & 0 & 0 \\
\hline A4 & $\begin{array}{l}\text { Forint állampapír } \\
\text { vásárlása }\end{array}$ & $\begin{array}{l}2 \text { éven túli } \\
\text { devizakülső bankközi } \\
\text { forrás bevonása }\end{array}$ & $\begin{array}{l}\text { Nevező } \\
\text { 个100\% }\end{array}$ & $\begin{array}{l}\text { Számláló } \\
\text { 个100\% }\end{array}$ & $\begin{array}{l}\text { Számláló } \\
\downarrow 100 \% \\
\text { Nevező } \\
\uparrow 100 \%\end{array}$ & $\begin{array}{c}\text { Számláló } \\
\text { 个100\% }\end{array}$ \\
\hline A5 & $\begin{array}{l}\text { Deviza lakossági } \\
\text { jelzáloghitelállomány } \\
\text { csökkentése (forin- } \\
\text { tosítás) }\end{array}$ & $\begin{array}{l}\text { Nincs (mérlegen } \\
\text { kívül van hatás, } \\
\text { devizaswap- } \\
\text { állományban) }\end{array}$ & 0 & $\begin{array}{l}\text { Nevező } \\
\downarrow 65 \%\end{array}$ & $\begin{array}{l}\text { Számláló } \\
\downarrow 100 \%\end{array}$ & 0 \\
\hline A6 & $\begin{array}{l}\text { Deviza lakossági } \\
\text { egyéb hitelállomány } \\
\text { csökkentése (forin- } \\
\text { tosítás) }\end{array}$ & $\begin{array}{l}\text { Nincs (mérlegen } \\
\text { kívül van hatás, } \\
\text { devizaswap- } \\
\text { állományban) }\end{array}$ & 0 & $\begin{array}{l}\text { Nevező } \\
\downarrow 85 \%\end{array}$ & $\begin{array}{l}\text { Számláló } \\
\downarrow 100 \%\end{array}$ & 0 \\
\hline \multicolumn{7}{|c|}{$\begin{array}{l}\text { Megjegyzés: *Ki- és beáramlási vonzatok pontos becslése, ahol releváns lenne, nem megoldható, az } \\
\text { LCR-mutató változásában csak a likvid eszközök állományának változása jelenik meg. Továbbá lásd a } 2 . \\
\text { táblázathoz füzött megjegyzést. }\end{array}$} \\
\hline
\end{tabular}

Az eddig bemutatott alkalmazkodási módok azon bankok alkalmazkodását segítik, amelyek főként forint forrásokból, valamint kisebb mértékben rövid bankközi devizaforrásokból finanszírozták devizahitelezésüket. A bankok egy kisebb része azonban másfajta üzleti modellel működött, amely fordított denominációs eltéréshez vezetett. Ezek a főként nyugat-európai nagybankok fióktelepeiként működő intézmények a hazai bankoknál olcsóbban és nagyobb mennyiségben jutottak devizaforrásokhoz, amelyet aztán a hazai szereplőkkel forintra cseréltek. Ezért általában devizaforrás-többlettel rendelkeztek, és a DEM-mutatójuk-15 százalék alatt volt ${ }^{13}$. Az ilyen intézmények alkalmazkodásához speciális alkalmazkodási módok definiálására volt szükség, mert a fentiekben definiált alkalmazkodási módok csak rontani tudták volna a DEM-megfelelésüket (4. táblázat).

\footnotetext{
${ }^{13}$ Bár a szabályozás a devizaeszközök és devizaforrások különbségének abszolút értékére vonatkozik, cikkünkben a DEM-értékek számításakor nem veszünk abszolút értéket, hanem előjelhelyesen alkalmazzuk a mutatót. Ennek az oka, hogy különböző alkalmazkodási módok szükségesek pozitív és negatív mutató, vagyis devizaeszköz- és devizaforrás-többlet esetén.
} 


\begin{tabular}{|c|c|c|c|c|c|c|}
\hline \multirow{2}{*}{\multicolumn{3}{|c|}{$\begin{array}{l}\text { 4. táblázat } \\
\text { "-15" százalék alatti DEM-mutatóval rende } \\
\text { azok sorrendje, valamint a mutatókra kifej } \\
\qquad \text { ALKALMAZKODÁSI MÓD }\end{array}$}} & $\begin{array}{l}\text { kező baı } \\
\text { ett hatás }\end{array}$ & k alkal & kodási & djai, \\
\hline & & & \multicolumn{4}{|c|}{ ALKALMAZKODÁSI MÓD HATÁSA A MUTATÓKRA } \\
\hline AM & Eszköz & Forrás & BFM & DMM & DEM & LCR* \\
\hline B1 & $\begin{array}{l}\text { Forint likvid eszköz } \\
\text { (állampapír) csök- } \\
\text { kentése }\end{array}$ & $\begin{array}{l}\text { 0-1 éves deviza bankkö- } \\
\text { zi külső forrás csökken- } \\
\text { tése (az anyabanktól } \\
\text { kapott, belföldi bankkal } \\
\text { forintra swapolt deviza- } \\
\text { hitelt visszaswapolja az } \\
\text { anyabankkal, és visz- } \\
\text { szafizeti a devizahitelt) }\end{array}$ & $\begin{array}{l}\text { Számláló } \\
\downarrow 100 \% \\
\text { Nevező } \\
\downarrow 100 \%\end{array}$ & 0 & $\begin{array}{l}\text { Számláló } \\
\text { 个100\% } \\
\text { Nevező } \\
\downarrow 100 \%\end{array}$ & $\begin{array}{l}\text { Számláló } \\
\downarrow 100 \%\end{array}$ \\
\hline B2 & $\begin{array}{l}\text { Deviza államköt- } \\
\text { vény, jegybanki } \\
\text { kötvény vásárlása }\end{array}$ & $\begin{array}{l}2 \text { éven túli deviza bank- } \\
\text { közi forrás bevonása }\end{array}$ & $\begin{array}{l}\text { Nevező } \\
\text { 个100\% }\end{array}$ & $\begin{array}{c}\text { Számláló } \\
\text { 个100\% } \\
\text { Nevező } \\
\text { 个5\% }\end{array}$ & $\begin{array}{l}\text { Nevező } \\
\uparrow 100 \%\end{array}$ & $\begin{array}{l}\text { Számláló } \\
\text { 个100\% }\end{array}$ \\
\hline
\end{tabular}

Megjegyzés: *Ki- és beáramlási vonzatok pontos becslése, ahol releváns lenne, nem megoldható, az LCR-mutató változásában csak a likvid eszközök állományának változása jelenik meg. Továbbá lásd a 2. táblázathoz füzött megjegyzést. Piros háttérrel a mutató romlását, zölddel a javulását jeleztük, DEM esetén negatív kiinduló értéket feltételezve.

Az egyes alkalmazkodási módoknál az intézmények bizonyos mérlegkorlátokba ütközhetnek (5. táblázat). Az egyes alkalmazkodási módokat tehát csak az adott mérlegtételek erejéig tudják igénybe venni a bankok: például az A1 módnál csak addig tudják az 1-2 éves forint bankközi külső forrásaikat devizára váltani, ameddig azok rendelkezésre állnak a mérlegükben. A feltételezett alkalmazkodási módok fényében négy ilyen korlátot jelentő mérlegtétel van, ezek közül két forrásoldali és két eszközoldali korlát áll fenn. A B2 és az első esetben az A4 alkalmazkodási módoknál nincs mérlegkorlát. A második esetben az első esetben fennálló korlátokon kívül az A4 mód is korlátos, ekkor feltételezésünk szerint csak a szükséges teljes külső forrás feléhez tudnak hozzájutni a bankok, ezért eszközoldali alkalmazkodás is szükséges.

\section{5. táblázat}

\section{Alkalmazkodási módok esetén jelentkező forrás- és eszközoldali mérlegkorlátok és tartalmuk}

\begin{tabular}{|c|c|c|c|}
\hline \multicolumn{2}{|c|}{ Mérlegkorlát } & Tartalma és indoka & $\begin{array}{c}\text { Alkalmazkodási } \\
\text { mód }\end{array}$ \\
\hline \multirow{2}{*}{ 뉸 } & $\begin{array}{l}\text { Bankközi 1-2 éves } \\
\text { és } 2 \text { éven túli külső } \\
\text { forintforrás }\end{array}$ & $\begin{array}{l}\text { A hosszú forint források deviza hosszú forrással való } \\
\text { kiváltása esetén, ami útján DMM és DEM javulást lehet } \\
\text { elérni. }\end{array}$ & $\mathrm{A} 1, \mathrm{~A} 2$ \\
\hline & $\begin{array}{l}\text { Bankközi 0-1 éves } \\
\text { külső devizaforrás }\end{array}$ & $\begin{array}{l}\text { Csak az eredetileg rövid, de nem látra szóló külföldi } \\
\text { bankközi deviza betétek és felvett hitelekkel számoltunk, } \\
\text { hiszen vélelmezhetően ez az az állomány, amelynek } \\
\text { hosszítása könnyen megoldható a bank számára. }\end{array}$ & A3, B1 \\
\hline \multirow[t]{2}{*}{ : } & Lakossági devizahitel & $\begin{array}{l}\text { A lakossági ingatlan fedezetű deviza (lakás célú és szabad } \\
\text { felhasználású) jelzáloghitelekkel és az egyéb lakossági } \\
\text { devizahitelekkel is számoltunk. }\end{array}$ & A5, A6 \\
\hline & Forint likvid eszközök & Az LCR számlálójával számoltunk. & B1 \\
\hline
\end{tabular}




\subsection{Adatok összegyưjtése, mutatók becslése}

A számítások elvégzéséhez egyrészt szükség volt az egyedi banki szabályozási mutatószámokra, másrészt az egyes alkalmazkodások esetén fennálló alkalmazkodási korlátokat adó mérlegtételekre. A szükséges adatok a bankok által teljesített felügyeleti adatszolgáltatásokból származnak. Ami a szabályozási mutatószámokat illeti, a szabályozások válság előtti hiánya miatt az azokhoz kapcsolódó adatszolgáltatások nem voltak elérhetők. Ráadásul a válság előtt lényegesen kevesebb, a mutatók becsléséhez kevésbé alkalmas adattömeg állt rendelkezésre. Ezért az adathiány miatt és az egyszerüsítés érdekében a mutatószámoknak csak a közelítése volt megoldható különböző specifikus megkötések mellett. Minél bonyolultabb mutatóról beszélünk, annál több megkötésre volt szükség:

- Az LCR esetén elsősorban egy egyszerübb mutató előállítására kellett törekedni a főbb tételek megragadásával.

- A DMM tekintetében a hátralévő lejáratok helyett eredeti lejáratokkal való számolás, egyes tételek esetén a devizális megbontású adatok hiánya miatt a devizaarány, valamint a mérlegen kívüli kötelezettségek becslése jelentett nehézséget.

- A BFM tekintetében szintén a hátralévő lejárat szerinti adatok hiánya, valamint a szabályozásban lévő mentesíthető kedvezménytételek becslése jelentette a problémát.

- A forrásoldali korlátok esetén szintén eredeti lejáratokkal számoltunk a válság előtti adatokon még nem elérhető hátralévő lejáratok helyett.

Mindezen becsléseket szúkített banki körre, 13 hazai nagybankra, közte a fontosabb fióktelepekre állítottuk elő. Az adatokat a 2003 és 2008 közötti hat év mindegyikére összegyűjtöttük és becsültük. A becsléseket az egyszerúsítés és az adatkorlátok miatt egyedi (nem konszolidált) szinten állítottuk elő.

\section{Eredmények}

Az összeállított adatokon szimulálva az alkalmazkodási módokat, az egyes mutatók változását és összetételét, illetve a deviza rövid bankközi külső források és a lakossági devizahitel-állomány évenkénti és éveken átívelő változását is vizsgáltuk. Néhány reális feltételezés teljesülése esetén (például, hogy a bankok először főként forrásoldalon alkalmazkodnának, illetve hogy már meglévő forrásaik legalább egy részét hosszú devizaforrásra cserélnék, mielőtt a mérlegük növelésével vonnák be őket), az alkalmazkodási módok sorrendjén történő kisebb módosítások nem változtatnának jelentősen a következőkben bemutatott eredményeken, és így a főbb konklúziókon. 


\subsection{A szabályozásnak való megfelelés alakulása}

A felvázolt módszertan és felállított alkalmazkodási módok szerint minden vizsgált bank közelített volna a szabályozói limitekhez, de nem minden bank ért volna el teljes megfelelést. Ehhez esetleg további, a módszertant érdemben bonyolító alkalmazkodási módozatokra lett volna szükség, ami a számítások célját és eredményét tekintve sem lett volna ésszerü.

A korlátlan forrásoldali alkalmazkodást megengedő első esetben minden mutatónak és minden évben meg tudott volna felelni az összes bank (4. ábra). Az eszközoldali alkalmazkodással kiegészülő második esetben a bankok jelentős része nem tudott volna elérni teljes megfelelést a háztartási devizahitel-állomány leépítésével annak korlátossága miatt, így csak javítani tudott volna a mutatóin. Ez a megfelelési probléma lényegében csak a DMM teljesítésénél jelentkezett. A 2000-es évek elején a magas meg nem felelést az okozza, hogy akkor még alacsony volt és fokozatosan épült fel a lakossági devizahitel-állomány, inkább a vállalati devizahitelek voltak jellemzők. Ezek hirtelen leépítése a bankok múködésére és a tágabb gazdaságra is rendkívül negatív hatással lett volna, ezért ezt nem vettük fel a lehetséges igazodási módok közé. Hozzá kell tenni azt is, hogy a valóságban egy ilyen szabályozás bevezetését jellemzően hosszú felkészülési időszak előzi meg, amely akár éveket is jelenthet, így a bankoknak megfelelő idő áll rendelkezésükre akár teljes eszköz- és forrásszerkezetük fokozatos átalakítására.

\section{4. ábra \\ A szabályozásoknak megfelelő bankok száma az alkalmazkodás előtt, valamint az alkalmazkodás után az 1 . és 2 . esetben}

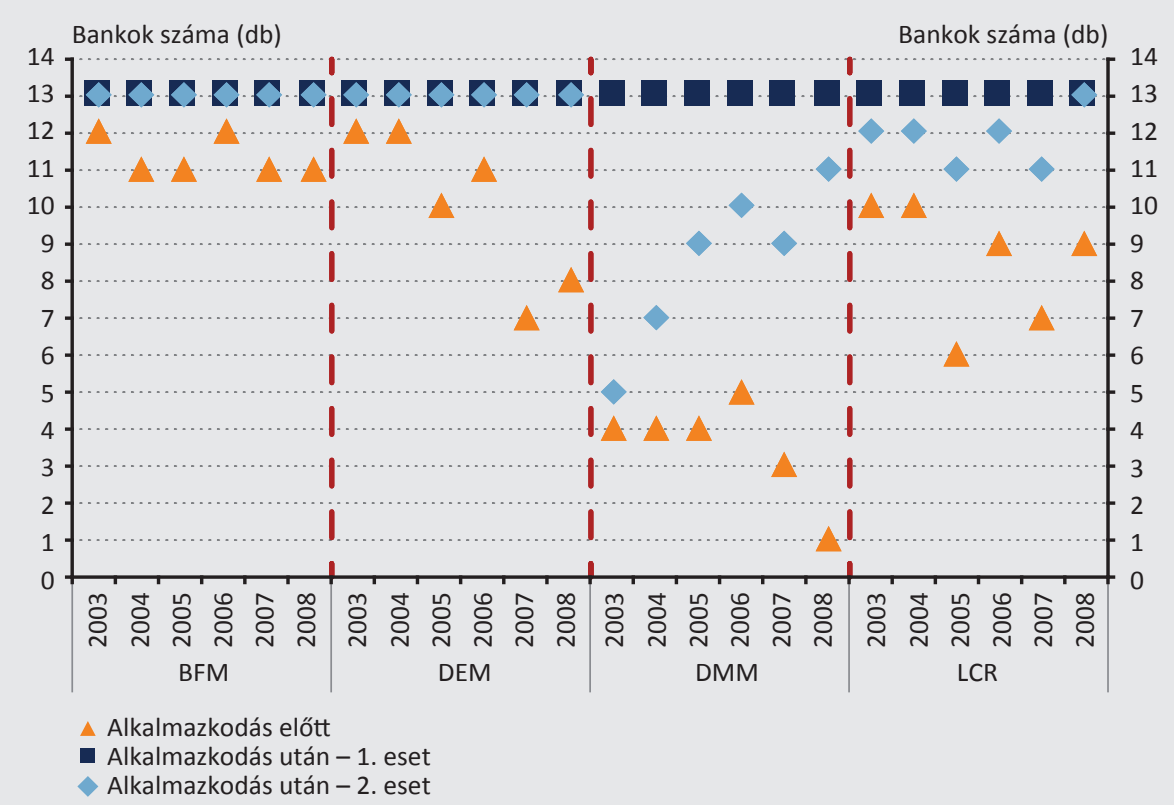

Forrás: MNB 
A BFM aktuálisan is preventív és szélsőséges banki modelleket célzó jellege miatt csak néhány bank, mindössze két fióktelep kényszerült volna alkalmazkodásra, teljes megfelelést elérve. Az esetek között nem jelentkezett különbség, mivel a BFM esetében eszközoldali alkalmazkodással nem lehet javítani a kizárólag forrásoldali eszközként operáló követelményt. A DEM esetében idővel egyre több bank kényszerült volna alkalmazkodásra, de az 1. és a 2. esetben is minden banknak sikerült volna a limiteken belülre kerülnie. A legnagyobb alkalmazkodást a DMM igényelte volna a bankoktól, néhány kivétellel minden bank alkalmazkodásra kényszerült volna. Az alkalmazkodás után csak az 1. esetben sikerült volna minden vizsgált intézménynek megfelelnie, hiszen jelentős lakosságidevizahitel-leépítésre lett volna szükség a 2. esetben, és a bankok többsége ebben az esetben végül nem tudott volna megfelelni a DMM-követelménynek. Az LCR esetén a legtöbb bank az alkalmazkodással meg tudott volna felelni az LCR követelménynek, bár a második esetben ez kevesebb intézménynek sikerült volna, mert a likvid eszközöket kevésbé érintő alkalmazkodás miatt kevesebb lehetőség lett volna az LCR-mutató javítására ${ }^{14}$.

A visszatesztelési vizsgálatunk eredménye szerint az idő előrehaladtával és a válsághoz közeledve a bankok részéről egyre nagyobb alkalmazkodásra lett volna szükség. Míg tehát a vizsgált szabályozási eszközök 2003-as bevezetése a legtöbb banktól csak kismértékű alkalmazkodást igényelt volna, 2008-ban ez már jelentős alkalmazkodási szükséglethez vezetett volna. Bár az egyes alkalmazkodási módok igénybevételének és a teljes alkalmazkodásnak a pontos mértéke ezek sorrendjétől függhet, az kijelenthető, hogy legnagyobb mértékben a hosszú külső bankközi forrásból való állampapírvásárlással, a rövid külső devizaforrások hosszításával és eszközoldali alkalmazkodási lehetőség esetén a lakossági devizahitelek forintosításával igazodhattak volna a bankok (5. ábra).

${ }^{14}$ A mutatók alakulására kifejtett hatást és banki eloszlását szabályozásonként a melléklet 10-13. ábrái mutatják be. 


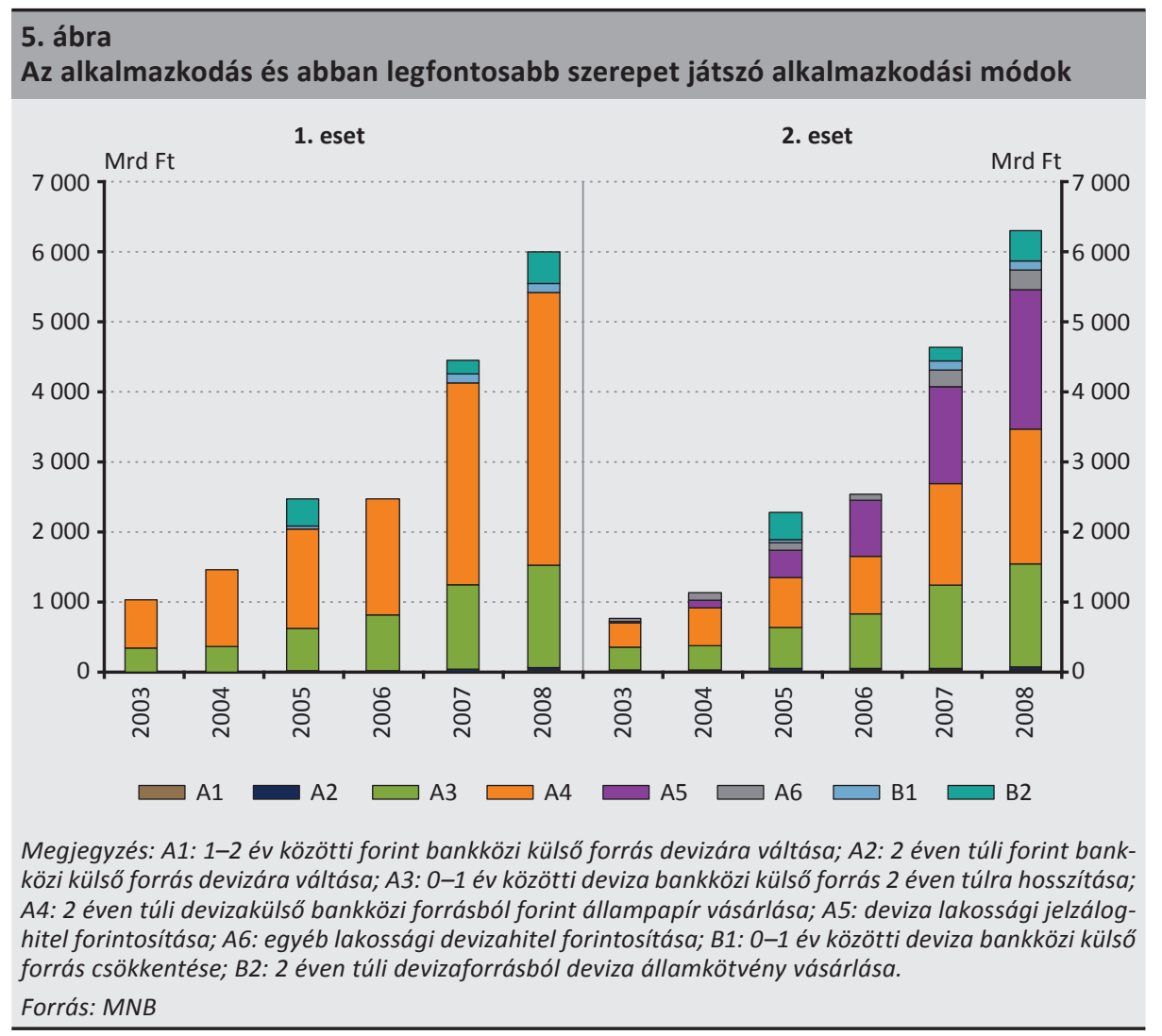

\subsection{Hatás a külső sérülékenységre és a hitelezésre}

A makrogazdasági szintű hatásokról elmondható, hogy a szabályozások válság előtti bevezetésével jelentősen alacsonyabban lehetett volna tartani a rövid külső adósság szintjét, és így a nemzetgazdaság külső sérülékenységét is (6. ábra). A bankközi rövid külső adósság mindkét vizsgált esetben érdemben kisebb lehetett volna a vizsgált évek mindegyikében, és különösen a válságot közvetlenül megelőző években, ami kisebb sérülékenységet és jelentősen kisebb nemzetközi tartalékigényt eredményezhetett volna. Eszközoldali alkalmazkodás esetén a rövid külső adósság mérséklődése erőteljes hitelállomány-leépítéssel is kiegészült volna. Ugyanakkor fontos hozzátenni, hogy a válság előtt közvetlenül történő bevezetés kései és sokkszerű lett volna, a jelentős alkalmazkodási kényszer miatt a megfelelés költsége is magas lett volna, ami az időzítés jelentőségére hívja fel a figyelmet. 


\section{6. ábra \\ A szabályozások bevezetésének banki rövid külső adósságra és a devizahitelekre kifejtett hatása}

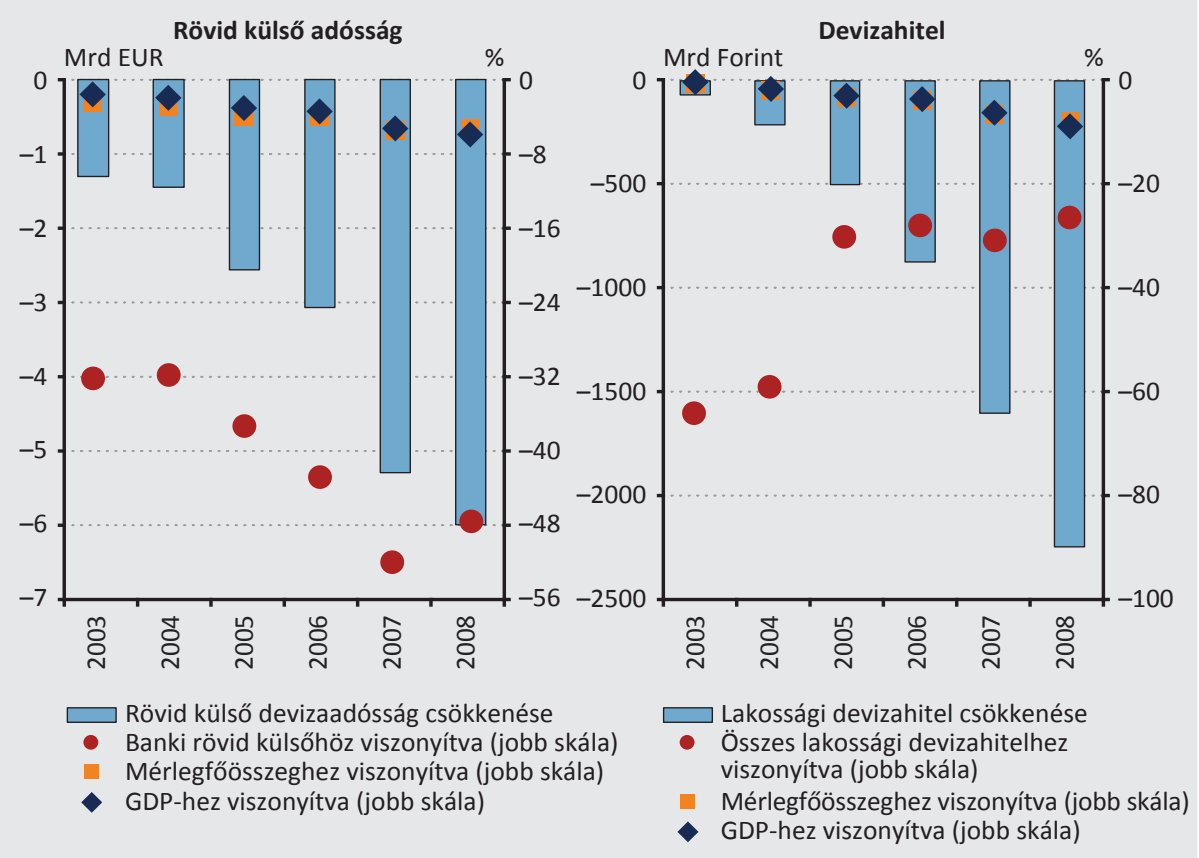

Megjegyzés: Amennyiben az eszköztár az adott évben lépett volna hatályba. Míg a rövid külső adósság csökkenése mindkét vizsgált esetre vonatkozik, addig a devizahitelek állománya csak a 2. esetben csökkent volna.

Forrás: $M N B$

A szabályozás hatására átlagosan a mérlegfőösszeg 3-6 százalékát elérő bankközi rövid külső devizaadósság csökkenésre lett volna szükség (7. ábra), de egyes intézményeknél elérhette volna a mérlegfőösszeg akár 30 százalékát is, különösen az ún. carry trade ${ }^{15}$ tevékenységben érintett fióktelepek, vagy a rövid külső anyabanki forrásra jelentős mértékben támaszkodó üzleti modellek esetében. Több banknak emellett a teljes lakossági devizahitel-állományát le kellett volna építenie. A szabályozás hatására a devizahitel-felfutás szakaszában átlagosan a mérlegfőösszeg 5-9 százalékát elérő alkalmazkodásra lett volna szükség, de az megközelíthette volna akár annak 20 százalékát is négy bank esetében.

\footnotetext{
${ }^{15}$ Ezen ügyleteknél tőkeáttételből történik eszközvásárlás (vagy pl. hitelkihelyezés). A devizapiaci carry trade esetében az egyik devizában alacsonyabb kamaton történő hitelfelvétel egy másik devizában magasabb kamaton való befektetéssel (pl. hitelkihelyezéssel) párosul.
} 


\section{7. ábra}

A mérlegfőösszeg-arányos rövid külső adósság és a devizahitelek változása és eloszlásának alakulása

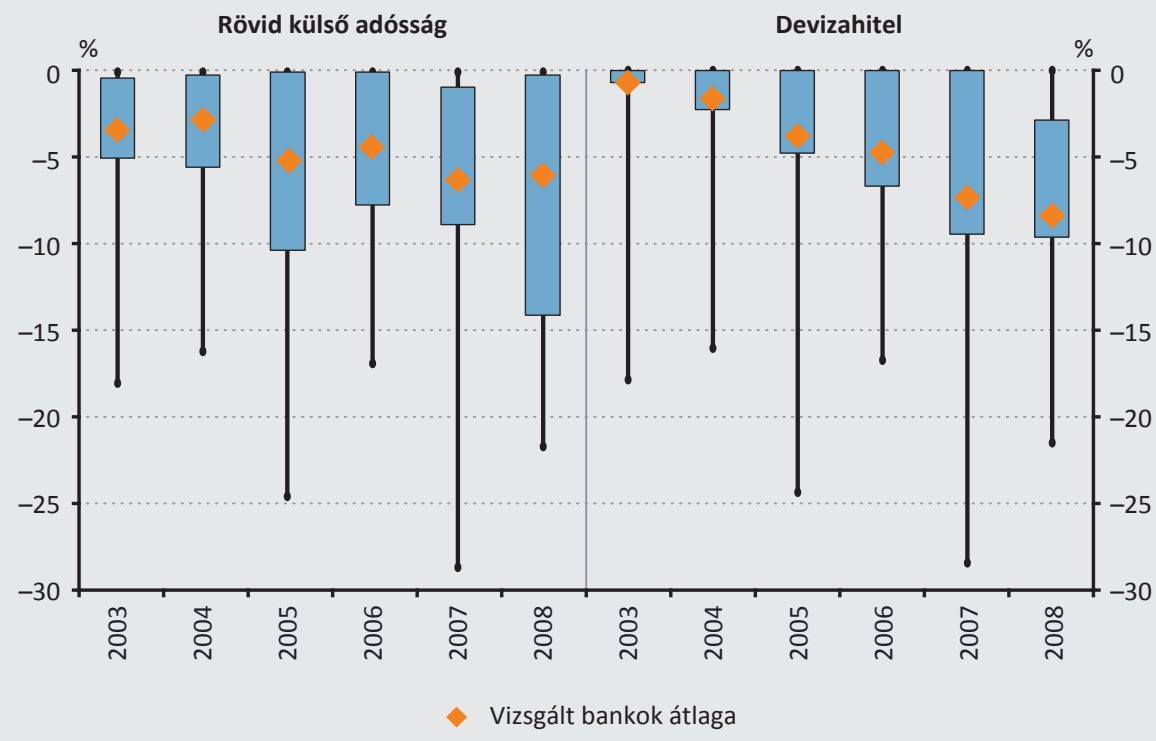

Megjegyzés: Amennyiben az eszköztár az adott évben lépett volna hatályba. Minimum és maximum, alsó és felső kvartilis értékek. Míg a rövid külső adósság csökkenése mindkét vizsgált esetre vonatkozik, addig a devizahitelek állománya csak a 2. esetben csökkent volna

Forrás: $M N B$

Amennyiben a szabályozást a hatóság 2003-ban bevezette volna és azt az azt követő években is fenntartotta volna, akkor a megvalósult banki rövid külső adósságpálya ismeretében jelentős, de évről évre változó mértékű rövid külső forrást szorított volna ki (8. ábra). Ugyanez történt volna a lakossági devizahitel-állománnyal is a megvalósult hitelpálya ismeretében. A szabályozás hatására kiszoruló devizahitel-állomány a forinthitelek jelentős felára miatt azonban csak részben lett volna ellensúlyozható a forinthitel-állomány növelésével, vagy az alkalmazkodási módoknál már jelzett forintosítással. 


\section{8. ábra \\ A szabályozások hatása a banki rövid külső adósságra és a devizahitelekre 2003-as bevezetés esetén}

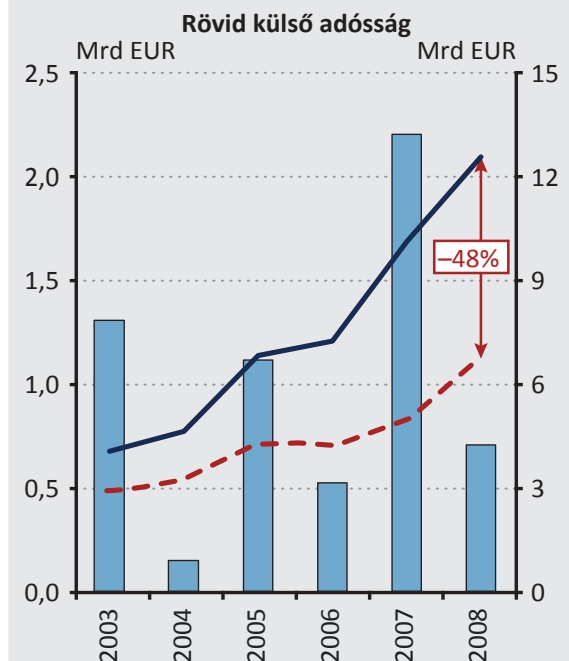

$\square$ Szabályozással kiszoruló banki rövid külső adósság

— - Szabályozott banki rövid külső adósság (jobb skála)

— Nem szabályozott banki rövid külső adósság (jobb skála)

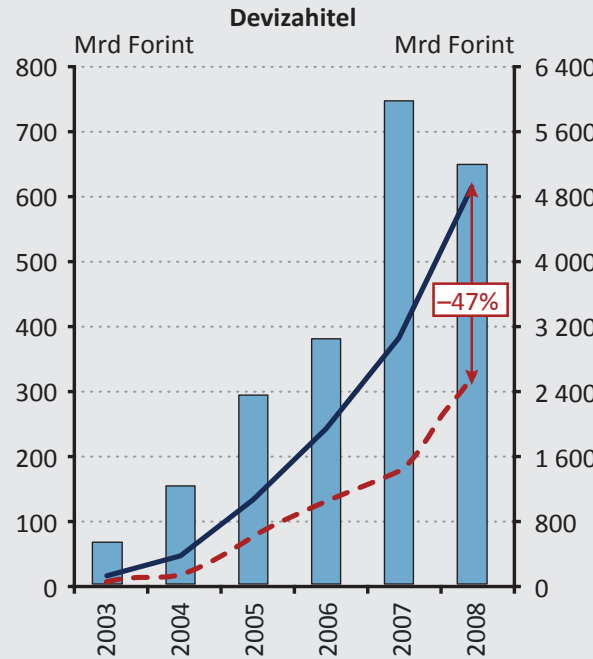

Szabályozás hatására kiszoruló devizahitel-állomány

- - Szabályozás melletti hitelállomány (jobb skála)

Szabályozás nélküli hitelállomány (jobb skála)

Megjegyzés: Az adott évi kiszoruló állomány azt mutatja, hogy az eszköztár 2003. évi bevezetése esetén mekkora állománybeli alkalmazkodási szükséglet maradt volna az adott évre. Míg a rövid külső adósság csökkenése mindkét vizsgált esetre vonatkozik, addig a devizahitelek állománya csak a 2. esetben csökkent volna.

Forrás: $M N B$

\subsection{Költségbecslés a hitelezésre kifejtett hatásokkal összefüggésben}

A költségeket a háztartások esetén a forint- és deviza hitelkamatok közötti különbségből fakadó adósságszolgálati teher növekedésével, a bankok esetén pedig a kieső devizahitel-állomány kapcsán elveszített adósságszolgálattal közelítettük. Az adósságszolgálat, illetve kieső adósságszolgálat éves mértékét az éves alkalmazkodási szükséglet esetén, különböző mértékű forint-hitelállománnyal való kiváltás mellett becsültük. A számításnál feltételezett átlagos futamidő 10 év volt. Az adósságszolgálati teher becslésénél alkalmazott képlet (Dynan et al. 2003 alapján) az alábbi volt:

$$
D S_{t}=D_{t} \cdot \frac{i_{t}}{\left(1-\left(1+i_{t}\right)^{-s_{t}}\right)}
$$

ahol $D S_{t}$ a $t$ időszakban számolt adósságszolgálati ráta, $D_{t}$ az adósság állománya, $i_{t}$ az átlagos éves kamatláb, $s_{t}$ az adósságállomány átlagos éves hátra lévő lejárata. 
A bankok esetében elsősorban az esetlegesen kieső hitelállomány, míg a háztartásoknál a forinthitelek jelentős felára eredményezett volna érdemi, növekvő többletköltséget attól függően, hogy mekkora devizahitel-állományt kellett volna leépíteni, illetve milyen mértékű forintosíthatóságot feltételezünk (9. ábra).

\section{9. ábra \\ A bankrendszer és a háztartások költsége a devizahitelek forintosítása esetén, eltérő szcenáriók mentén}

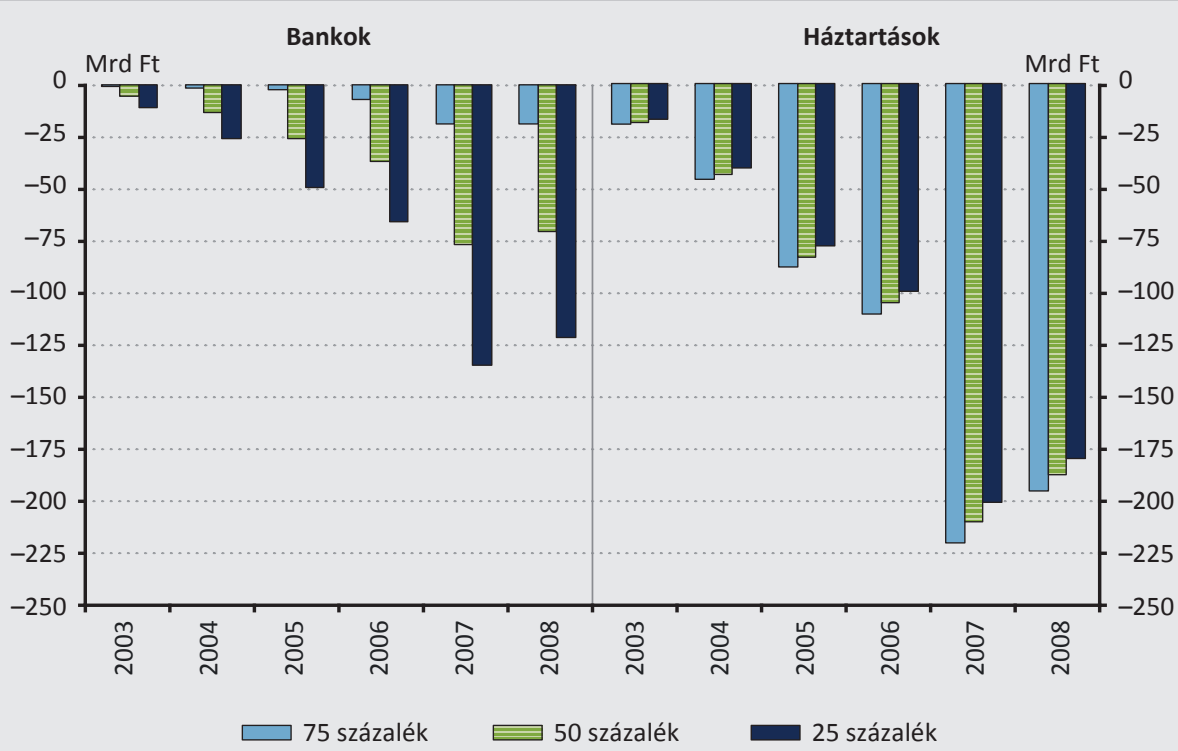

Megjegyzés: Háztartásoknál az adósságszolgálat (DS), bankoknál a kieső adósságszolgálat éves mértéke az éves alkalmazkodási szükséglet esetén, különböző mértékü forinthitel-állománnyal való kiváltás esetén, 10 éves átlagos hitelfutamidőt feltételezve. Elöző évi szabályozás esetén kiszoruló devizahitel és arányos kiváltás esetén.

Forrás: MNB

Bár tisztában vagyunk az imént ismertetett számítás közelítő jellegével, mindenképp említésre méltónak tartjuk, hogy ezek a költségek vélhetően messze elmaradtak volna a fenntarthatatlan banki modellel összefüggően, többek között a háztartások és a bankrendszer által a vállalt árfolyam- és hitelkockázat kapcsán realizált veszteségektől, és azok tovagyűrűző, közismerten magas nemzetgazdasági költségeitől. A lakossági devizahitel-állomány túlnyomó részét kitevő svájcifrank-hitelek esetében, pusztán a svájci frank forinttal szembeni 2008 és a 2014. novemberi technikai forintosítási időpont közötti 60 százalékos erősödése miatt a 2008 végére a becslésünk által kimutatott mintegy 2300 milliárd forintnyi kiszorított devizahitel kapcsán közel 1400 milliárd forintnyi átértékelődési hatás jelentkezhetett az ezen időszakban megvalósuló törlesztőrészlet-változás, valamint a 2014-ben fennmaradó tőke te- 
kintetében. ${ }^{16}$ Vagyis a szabályozás korai bevezetése ekkora veszteségtől kímélhette volna meg a lakosságot, ami önmagában is többszörösen meghaladja az általunk becsült együttes háztartási és banki veszteséget. A szabályozások a kockázatok internalizálásán keresztül a túlzott banki és háztartási kockázatvállalás mérséklését szolgálták volna.

\section{6. Összegzés}

A 2008-as pénzügyi világválság tapasztalataira építve az MNB átfogó szabályrendszert hozott létre, amely elsősorban a devizális eltérést és a rövid lejáratú likviditást kezelő előírásokat foglalta magában. Ahhoz, hogy hozzávetőleges képet alkothassunk arról, hogy ezek milyen mértékben csökkentik a bankrendszer és ezáltal a gazdaság sérülékenységét, azt vizsgáltuk, hogy milyen hatása lett volna a fent leírt szabályrendszer válság előtti implementálásának. A visszatesztelési számítás arra enged következtetni, hogy a 2012-től bevezetett likviditási és finanszírozási szabályozások a válságot megelőző bevezetés esetén érdemben mérsékelhették volna mind a bankok egyedi, mind a bankszektor és a nemzetgazdaság egészének sérülékenységét.

A szabályozásoknak való megfelelés tekintetében kijelenthető, hogy a kizárólag forrásoldali alkalmazkodás esetén minden bank javított volna mutatóin, ezzel teljes megfelelést elérve. A forrásoldali alkalmazkodás korlátozása és eszközoldali alkalmazkodás megengedése esetén azonban a bankoknak mintegy fele nem tudott volna minden előírásnak megfelelni, ha csak azokra az alkalmazkodási eszközökre támaszkodik, amelyeket könnyen megvalósíthatónak és arányosan költséghatékonynak ítéltünk meg. A legnagyobb alkalmazkodásra minden esetben a DMM késztette volna a bankokat: eszközoldali alkalmazkodás esetén ezt sikerült volna a legritkábban teljesíteni.

A visszatesztelés eredményei azt mutatják, hogy a bankközi rövid külső adósság minden esetben jelentősen alacsonyabb lett volna, ami érdemben kisebb sérülékenységet és kisebb nemzetközi tartalékigényt jelenthetett volna. Az eszközoldali alkalmazkodás esetén pedig a lakossági devizahitel-állománynak érdemben csökkennie kellett volna forintosítás útján, illetve eleve nem tudott volna felépülni a szabályozási korlátok miatt. Ezek az igazodások érdemben javíthattak volna a pénzügyi rendszer stabilitásán, ezáltal mérsékelve a nemzetgazdaság sérülékenységét. Végül, az általunk végzett elemzés a megfelelő ütemezés jelentőségét is kiemeli. Az alkalmazkodással felmerülő költségek vélhetően jelentősen elmaradtak volna a helytelen finanszírozási és hitelezési gyakorlatokból eredő veszteségekhez képest, de a szükséges alkalmazkodás mértéke 2008-as bevezetés esetén már sokként érte

${ }^{16}$ A forinthitelek magasabb kamata által okozott tehernövekedést a szabályozás költségei között már számításba vettük. 
volna a bankrendszert. Ez azonban megfelelően kommunikált, időszerű bevezetés esetén elkerülhető lett volna.

Elemzésünk az MNB hatályos likviditási és finanszírozási eszköztárának visszatesztelésével rámutatott, hogy az alkalmazott szabályok hatékony gátját képezhetik a válságok, így akár a mostani koronavírus világjárvány nyomán keletkező pénzügyi stresszhelyzet kialakulásának. A vizsgált szabályrendszer megakadályozhatja, hogy a bankok túlzott mértékben hagyatkozzanak kockázatosabbnak minősülő rövid lejáratú, elsősorban deviza külső forrásokra, pénzügyi vállalatoktól származó forrásokra, vagy mérlegen kívüli derivatív ügyletekre. Elemzésünk alapján tehát kijelenthető, hogy a tesztelt eszközök - az ilyen finanszírozási gyakorlat háztartási és bankrendszeri költségének internalizálásával - képesek lehettek volna a túlzott devizahitelezéssel kapcsolatos kockázatok, valamint az ezekkel összefüggésben realizált nemzetgazdasági szinten jelentős költségek mérséklésére is.

\section{Felhasznált irodalom}

Acharya V. - Schaefer, S. (2005): Understanding and managing correlation risk and liquidity risk. International Financial Risk Institute (IFRI) Roundtable, 29-30 September.

Balás Tamás - Móré Csaba (2007): Likviditási kockázat a magyar bankrendszerben. MNBtanulmányok 69., Magyar Nemzeti Bank, december. https://www.mnb.hu/letoltes/mt-69. pdf

BCBS (2000): Sound practices for managing liquidity in banking organisations. Basel Committee on Banking Supervision, February. https://www.bis.org/publ/bcbsc135.pdf

BCBS (2009): Findings on the interaction of market and credit risk. Working Paper Series No. 16., Basel Committee on Banking Supervision, May. https://www.bis.org/publ/bcbs_wp16. pdf

BCBS (2013): Basel III: The Liquidity Coverage Ratio and liquidity risk monitoring tools. Basel Committee on Banking Supervision, January. https://www.bis.org/publ/bcbs238.pdf

BCBS (2014): Basel III: the net stable funding ratio. Basel Committee on Banking Supervision, October. https://www.bis.org/bcbs/publ/d295.pdf

Baudino, P. - Sturluson, J.T. - Svoronos, J-P. (2020): The banking crisis in Iceland. FSI crisis management series No. 1, Bank for International Settlements. https://www.bis.org/fsi/ fsicms1.pdf 
Brunnermeier, M.K. - Pedersen, L.H. (2007): Market Liquidity and Funding Liquidity. NBER Working Paper No. 12939, National Bureau of Economic Research. https://doi. org/10.3386/w12939

Csávás Csaba (2015): A devizatartalék-megfelelés értékelésének nemzetközi trendjei. Szakmai cikk, Magyar Nemzeti Bank, július. https://www.mnb.hu/letoltes/csavas-csabaa-devizatartalek-megfeleles-ertekelesenek-nemzetkozi-trendjei.pdf. Letöltés ideje: 2020. március 10.

Dell'Ariccia, G. - Deniz, I. - Laeven, L.A. (2012): Credit booms and lending standards: Evidence from the subprime mortgage market. Journal of Money, Credit and Banking, 44(2-3): 367-384. https://doi.org/10.1111/j.1538-4616.2011.00491.x

Demyanyk, Y. - Hemert, O. Van (2011): Understanding the Subprime Mortgage Crisis. Review of Financial Studies, 24(6): 1848-1880. https://doi.org/10.1093/rfs/hhp033

Dudley, W. (2014): Welcome remarks. President and Chief Executive Officer of the Federal Reserve Bank of New York, at the workshop on the "Risks of Wholesale Funding", New York City, 13 August.

Dynan, K. - Johnson, K. - Pence, K. (2003): Recent changes to a measure of US household debt service. Federal Reserve Bulletin, 89(10): 417-426.

ECB (2002): Developments in bank's liquidity profile and management. European Central Bank, May. https://www.ecb.europa.eu/pub/pdf/other/banksliquidityprofile02en.pdf

ECB (2010): Financial stability review. European Central Bank, June. https://www.ecb.europa. eu/pub/pdf/fsr/financialstabilityreview201006en.pdf

Fábián Gergely - Vonnák Balázs (szerk.) (2014): Átalakulóban a magyar bankrendszer. Vitainditó a magyar bankrendszerre vonatkozó konszenzusos jövőkép kialakításához. MNB-tanulmányok 112., különszám, Magyar Nemzeti Bank. https://www.mnb.hu/letoltes/ mt112-kulonszam.pdf

Hahm, J.H. - Shin, H.Y. - Shin, K. (2013): Non-Core Bank Liabilities and Financial Vulnerability. Journal of Money, Credit and Banking, 45(s1): 3-36. https://doi.org/10.1111/jmcb.12035

Hartmann, P. (2010): Interaction of market and credit risk. Journal of Banking and Finance. 34(4): 697-702. https://doi.org/10.1016/j.jbankfin.2009.10.013

Huang, R. - Ratnovski, L. (2011): The dark side of bank wholesale funding. Journal of Financial Intermediation, 20(2): 248-263. https://doi.org/10.1016/j.jfi.2010.06.003 
Iyer, R. - Peydró, J-L. (2011): Interbank contagion at work: Evidence from a natural experiment. The Review of Financial Studies, 24(4): 1337-1377. https://doi.org/10.1093/ rfs/hhp105

Nagy Márton - Szabó E. Viktor (2008): Az amerikai másodrendü jelzáloghitel-piaci válság és hatásai a magyar bankrendszerre. MNB-szemle, 2008(április): 34 -43. https://www.mnb. hu/letoltes/nagy-marton-szabo-e-viktor.pdf

Nagy Márton - Palotai Dániel (2014): A devizatartalék óvatosan csökkenthető. Szakmai cikk, Magyar Nemzeti Bank, április. https://www.mnb.hu/letoltes/a-devizatartalek-ovatosancsokkentheto-2014-04-22.pdf. Letöltés ideje: 2020. április 6.

Nagy Márton - Vonnák Balázs (2014): Egy jól müködő magyar bankrendszer 10 ismérve. Szakmai cikk, Magyar Nemzeti Bank, március. https://www.mnb.hu/sajtoszoba/hirek-2015juniusig/nagy-marton-vonnak-balazs-egy-jol-mukodo-magyar-bankrendszer-10-ismerve. Letöltés ideje: 2020. április 10.

Páles Judit - Kuti Zsolt - Csávás Csaba (2010): A devizaswapok szerepe a hazai bankrendszerben és a swappiac válság alatti müködésének vizsgálata. MNB-tanulmányok 90. Magyar Nemzeti Bank. https://www.mnb.hu/letoltes/mt-90.pdf

Poghosyan, T. - Čihák M. (2009): Distress in European Banks: An Analysis Based on a New Data Set. IMF Working Paper No. 09/9. https://doi.org/10.5089/9781451871562.001

PSZÁF (2013): Kockázati Jelentés 2013/l. Pénzügyi Szervezetek Állami Felügyelete, június.

Ratnovski, L. - Huang, R. (2009): Why Are Canadian Banks More Resilient? IMF Working Paper No. 09/152. https://doi.org/10.5089/9781451872996.001

Sharma, P. (2004): Speech on liquidity risk. Financial Services Authority, London, October.

Yorulmazer, T. - Goldsmith-Pinkham, P. (2010): Liquidity, Bank Runs, and Bailouts: Spillover Effects During the Northern Rock Episode, Journal of Financial Services Research, 37: 83-98. https://doi.org/10.1007/s10693-009-0079-2 


\section{Melléklet}

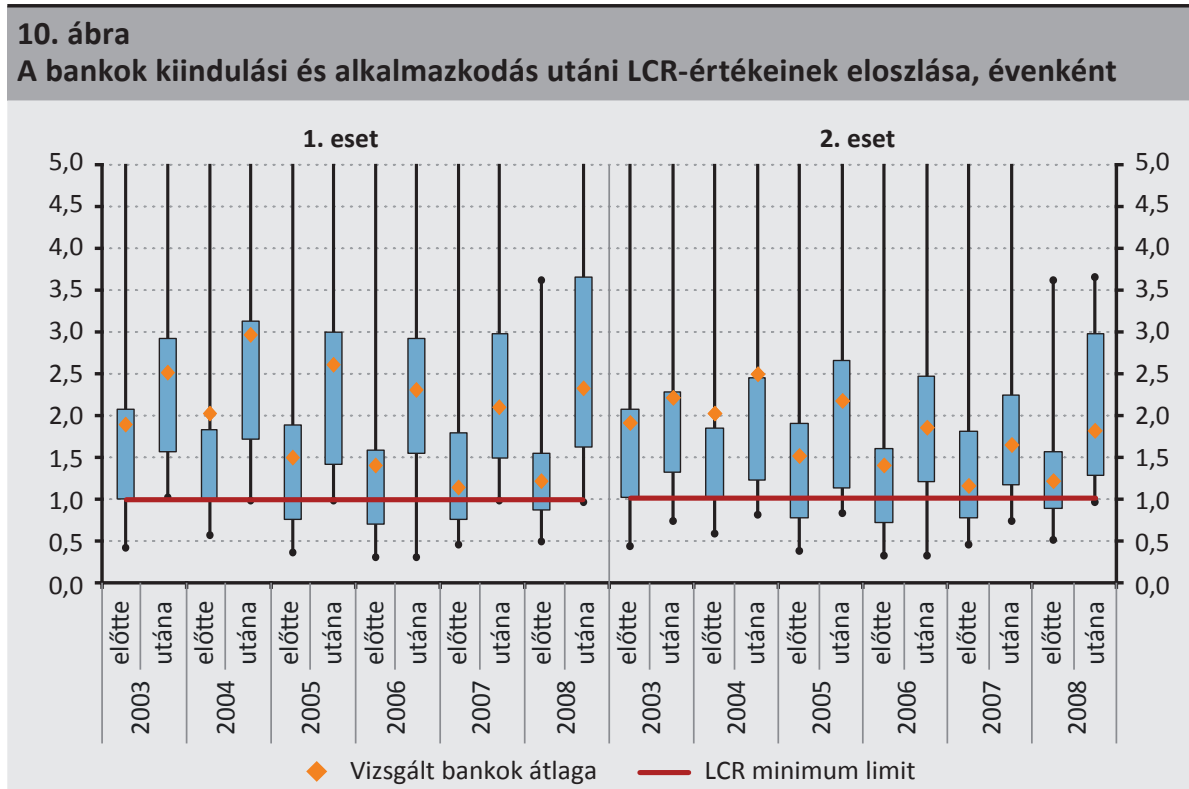

Megjegyzés: Az ábrán a minimum és maximum értékek, az első és harmadik kvartilis, valamint az átlag látható.

Forrás: $M N B$

\section{1. ábra}

\section{A bankok kiindulási és alkalmazkodás utáni DEM-értékeinek eloszlása, évenként}

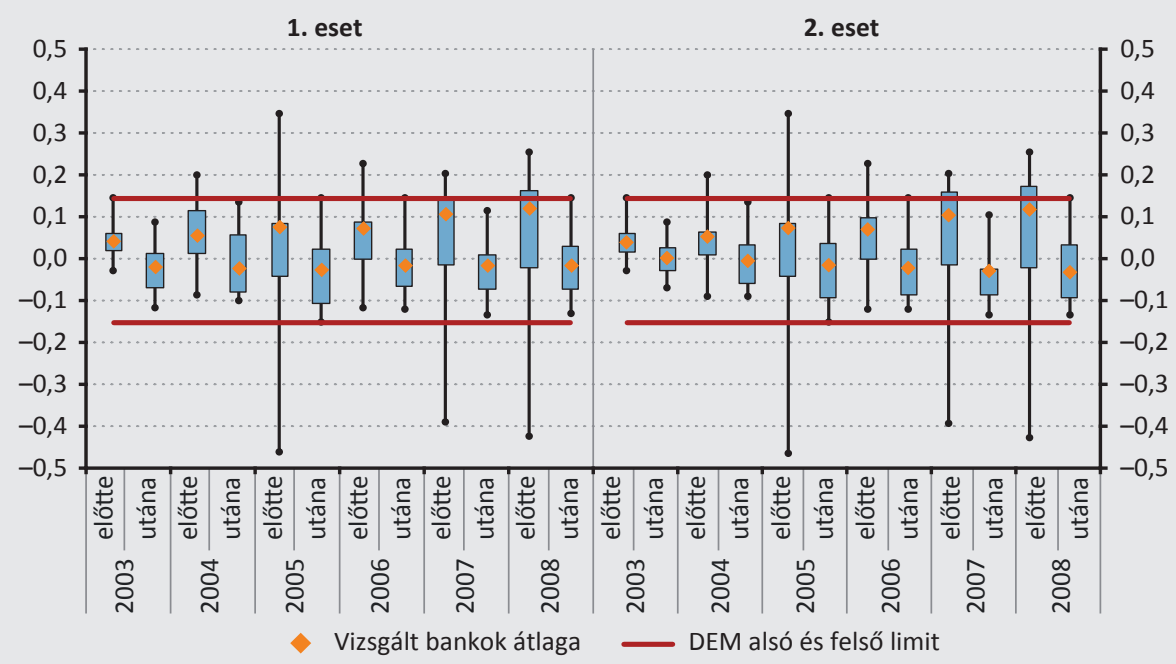

Megjegyzés: Az ábrán a minimum és maximum értékek, az első és harmadik kvartilis, valamint az átlag látható.

Forrás: $M N B$ 


\section{2. ábra}

A bankok kiindulási és alkalmazkodás utáni DMM-értékeinek eloszlása, évenként

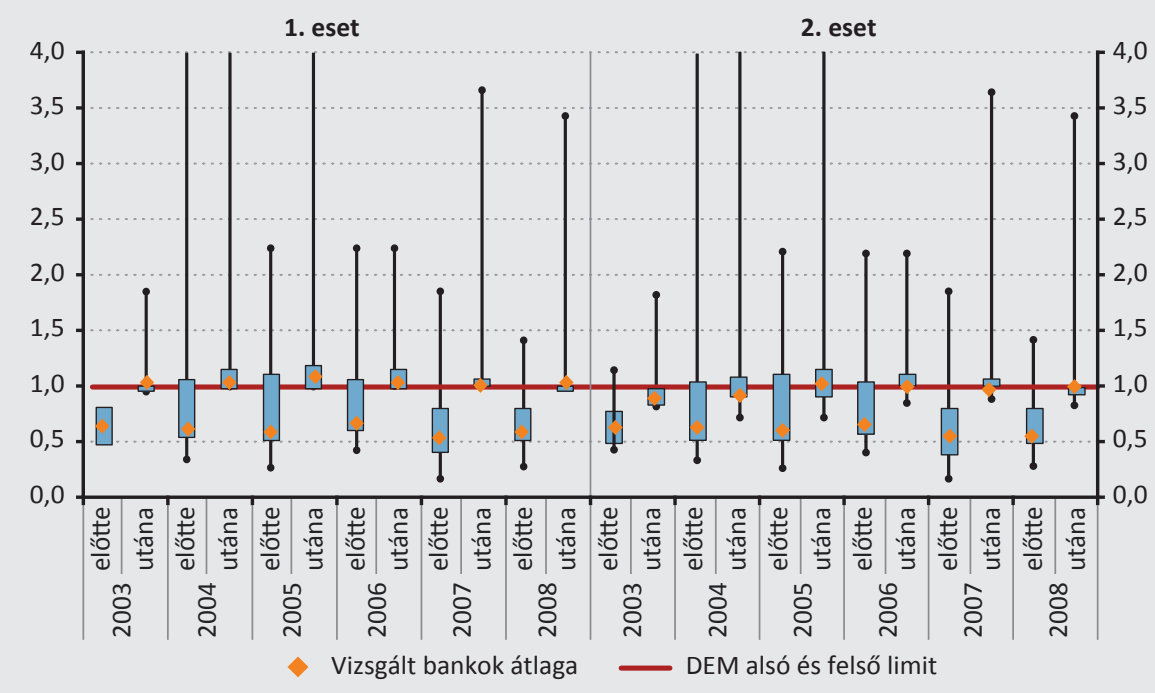

Megjegyzés: Az ábrán a minimum és maximum értékek, az első és harmadik kvartilis, valamint az átlag látható.

Forrás: MNB

13. ábra

A bankok kiindulási és alkalmazkodás utáni BFM-értékeinek eloszlása, évenként

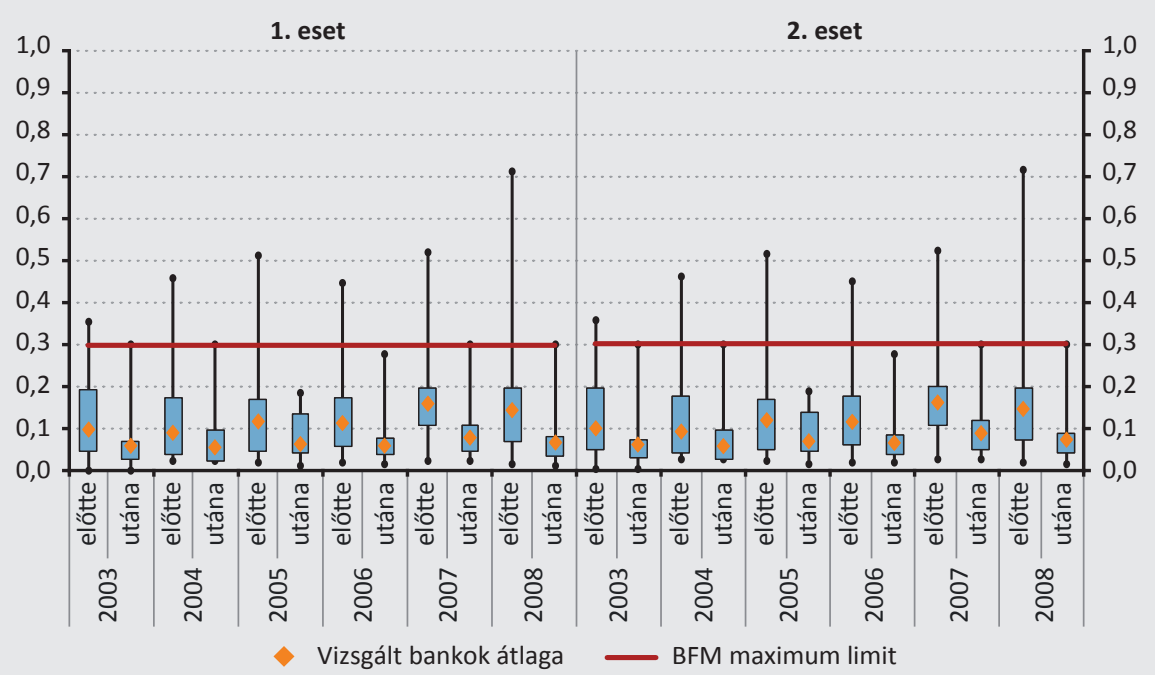

Megjegyzés: Az ábrán a minimum és maximum értékek, az első és harmadik kvartilis, valamint az átlag látható.

Forrás: MNB 